RECEIVED

MAR 251996

OSTI

\title{
BIOLOGICAL ASSESSMENT OF
}

REMEDIAL ACTION AT THE

\section{Abandoned URANiUm Mill Tallings Site Near Naturita, Colorado}

\section{March 1996}

\section{DISCLAIMER}

This report was prepared as an account of work sponsored by an agency of the United States Government. Neither the United States Government nor any agency thereof, nor any of their employees, makes any warranty, express or implied, or assumes any legal liability or responsibility for the accuracy, completeness, or usefulness of any information, apparatus, product, or process disclosed, or represents that its use would not infringe privately owned rights. Reference herein to any specific commercial product, process, or service by trade name, trademark, manufacturer, or otherwise does not necessarily constitute or imply its endorsement, recommendation, or favoring by the United States Government or any agency thereof. The views and opinions of authors expressed herein do not necessarily state or reflect those of the United States Government or any agency thereof. 
This report has been reproduced from the best available copy.

Number of pages in this report: 58

For availability contact:

Office of Scientific and Technical Information

P.O. Box 62

Oak Ridge, TN 37831

(615) 576-8401 
REV. 0

BIOLOGICAL ASSESSMENT OF REMEDIAL ACTION AT THE ABANDONED URANIUM MILL TAILINGS SITE NEAR NATURITA, COLORADO

March 1996

Prepared for

U.S. Department of Energy

Environmental Restoration Division UMTRA Project Team

Albuquerque, New Mexico

Prepared by

Jacobs Engineering Group Inc.

Albuquerque, New Mexico 


.




\section{TABLE OF CONTENTS}

Section

Page

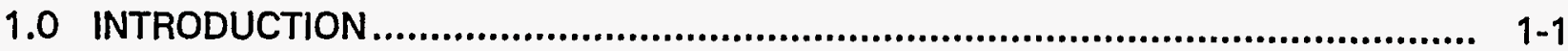

2.0 FLORA AND FAUNA....................................................................... $2-1$

2.1 Naturita processing site ................................................................... 2-1

2.2 Upper Burbank Quarry, Uravan, disposal site and Upper Club

Mesa borrow site ................................................................................ 2-11

2.3 Haul roads..................................................................................... 2-11

2.4 Proposed action ............................................................................... 2-13

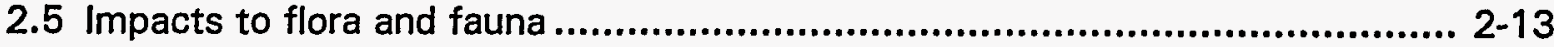

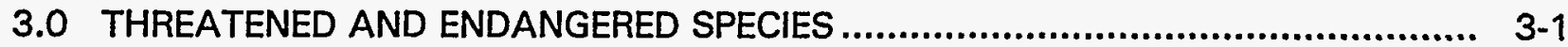

3.1 Mammals ..................................................................................... $3-1$

3.2 Birds........................................................................................ $3-1$

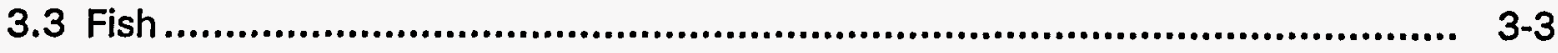

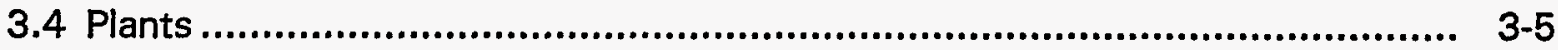

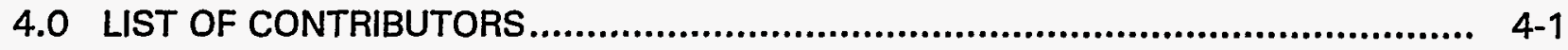

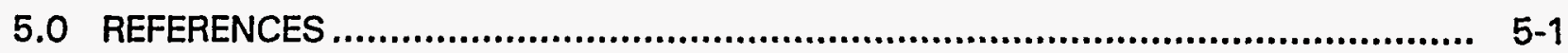

APPENDIX A CORRESPONDENCE WITH THE FISH AND WILDLIFE SERVICE 


\section{LIST OF FIGURES}

Figure

Page

1.1 Location of the Naturita site, Colorado..................................................... 1-2

2.1 Riparian plant community types along the San Miguel River in the area of the Naturita processing site, Colorado

2.2 Uravan disposal facility (Upper Burbank Quarry) and Upper Club Mesa borrow site at the Uravan site in Montrose County, Colorado

\section{LIST OF TABLES}

Table

2.1 Plant species observed in the area of the Naturita site, Colorado

2.2 Fish species recorded in the San Miguel River at the Naturita site, Colorado .......... 2-4

2.3 Amphibians and reptiles observed or expected to occur in the area of the Naturita site, Colorado

2.4 Bird species observed in the area of the Naturita site, Colorado.

2.5 Mammals observed or expected to occur in the area of the Naturita site, Colorado.

2.6 Nesting birds recorded from the riparian zone along a 1.3-mi $(2.1-\mathrm{km})$ stretch of the San Miguel River near the Naturita, Colorado, UMTRA Project site 


\section{LIST OF ACRONYMS}

$\begin{array}{ll}\text { Acronym } & \begin{array}{l}\text { Definition } \\ \text { CERCLA }\end{array} \\ \text { CDPHE } & \begin{array}{l}\text { Comprehensive Environmental Response, Compensation, and } \\ \text { Liabity Act }\end{array} \\ \text { Colorado Department of Public Health and Environment } \\ \text { dichlorodiphenylthrichloroethane } \\ \text { DOE } & \text { U.S. Department of Energy } \\ \text { EA } & \text { environmental assessment } \\ \text { EPA } & \text { U.S. Environmental Protection Agency } \\ \text { FWS } & \text { U.S. Department of the Interior, Fish and Wildife Service } \\ \text { RCD } & \text { Radiation Control Division } \\ \text { RRM } & \text { residual radioactive materials } \\ \text { UMTRA } & \text { Uranium Mill Tailings Remedial Action } \\ \text { UMTRCA } & \text { Uranium Mill Tailings Radiation Control Act } \\ \text { USACE } & \text { U.S. Army Corps of Engineers }\end{array}$




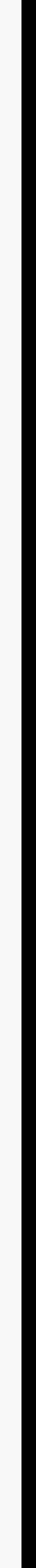




\subsection{INTRODUCTION}

Pursuant to the Uranium Mill Tailings Radiation Control Act (UMTRCA) of 1978, the U.S. Department of Energy (DOE) is proposing to conduct remedial action to clean up the residual radioactive materials (RRM) at the Naturita uranium processing site in Colorado. The Naturita site is in Montrose County, Colorado, and is approximately 2 miles (mi) 3 kilometer [km]) from the unincorporated town of Naturita (Figure 1.1). The site is on the west bank of the San Miguel River, which is a tributary of the Dolores River.

The proposed remedial action is to remove the RRM from the Naturita site to the Upper Burbank Quarry at the Uravan disposal site. To address the potential impacts of the remedial action on threatened and endangered species, the DOE prepared this biological assessment. Informal consultations with the U.S. Department of the Interior, Fish and Wildlife Service (FWS) were initiated in 1986, and the FWS provided a list of the threatened and endangered species that may occur in the Naturita study area. This list was updated by two FWS letters in 1988 and by verbal communication in 1990 (Leachman, 1990). A biological assessment was included in the environmental assessment (EA) of the proposed remedial action that was prepared in 1990. This EA addressed the impacts of moving the Naturita RRM to the Dry Flats disposal site.

In 1993, the design for the Dry Flats disposal alternative was changed. The FWS was again consulted in 1993 and provided a new list of threatened and endangered species that may occur in the Naturita study area. The Naturita EA and the biological assessment were revised in response to these changes (DOE, 1994). In 1994, remedial action was delayed because an alternate disposal site was being considered. The DOE decided to move the RRM at the Naturita site to the Upper Burbank Quarry at the Uravan site. Due to this delay, the FWS was consulted in 1995 and a list of threatened and endangered species was provided (see Appendix A). This biological assessment is a revision of the assessment attached to the Naturita EA (DOE, 1994) and addresses moving the Naturita RRM to the Upper Burbank Quarry disposal site. Copies of all correspondence with the FWS are provided in Appendix $A$ to this biological assessment.

For this biological assessment, the Naturita study area consists of the Naturita processing site, the Upper Burbank Quarry at the Uravan site, the Upper Club Mesa borrow site at the Uravan site, and the associated haul road. The study area is in the Great Basin sagebrush habitat of the Colorado Plateau (Kuchler, 1975). The processing site is in the San Miguel River valley, which is surrounded by steep juniper-covered hillsides. Flat land is confined to the riparian zone along the river. The Upper Burbank Quarry disposal site and the Upper Club Mesa borrow site are in disturbed land in upland areas surrounded by sagebrush and pinon-juniper plant communities. 
Figure 1.1

Location of the Naturita Site, Colorado

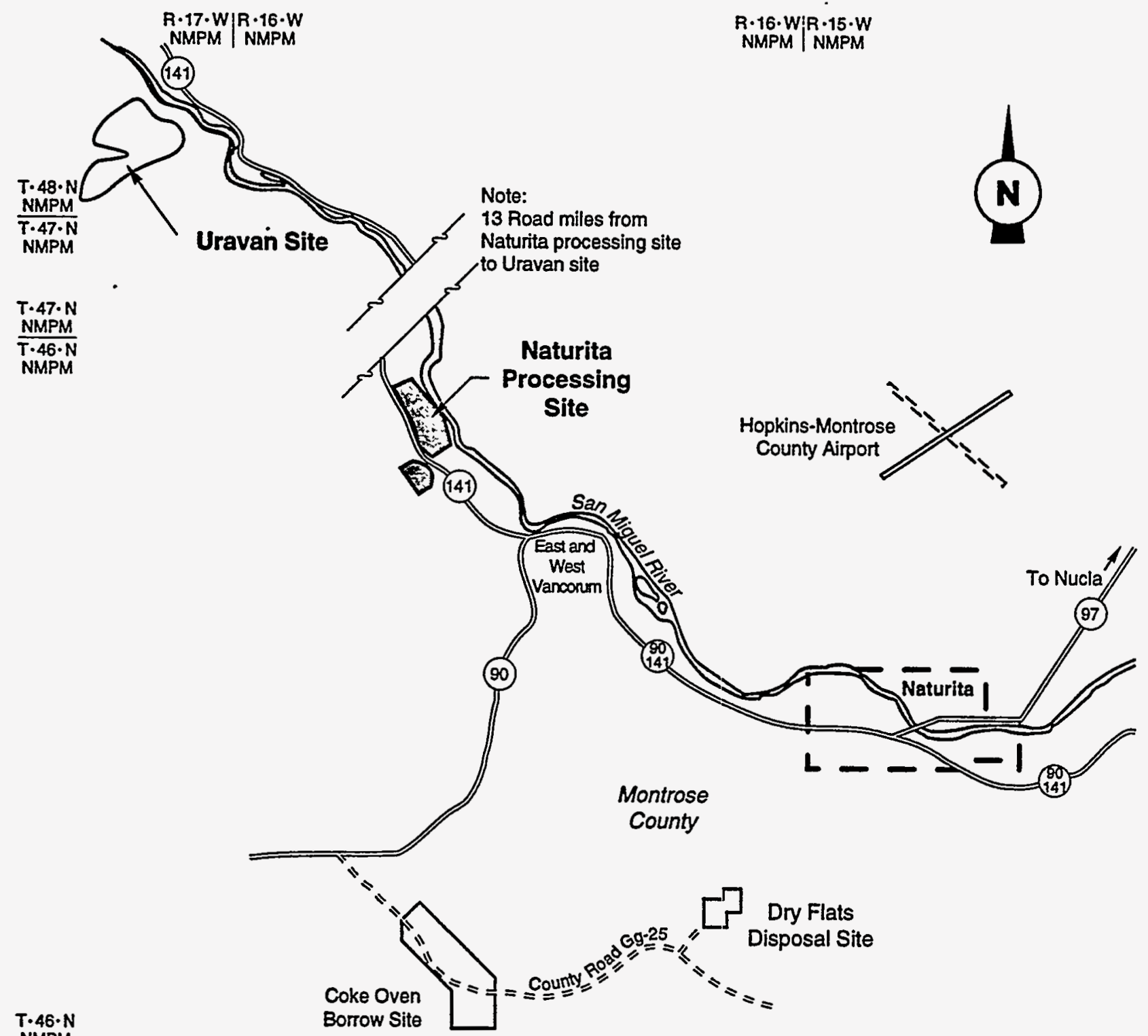

NMPM

$\overline{T \cdot 45 \cdot N}$

NMPM

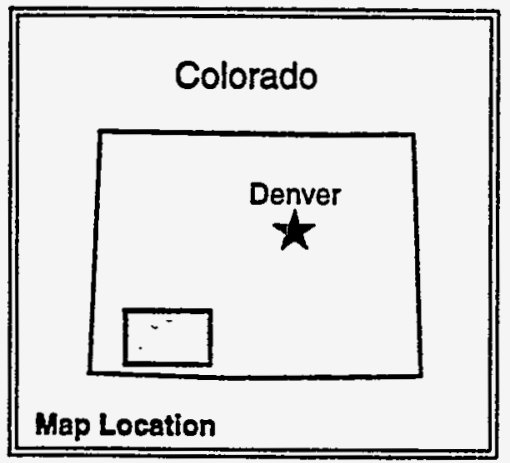

Not to scale

Legend

(90) State Highway

$==\mathbf{D}$ Dirt Road 


\subsection{FLORA AND FAUNA}

Information on the flora and fauna in the Naturita study area was obtained from field reconnaissance surveys (TAC, 1995, 1994a, 1993, 1992, 1991, 1990, 1988, 1986; DOE, 1983), consultations with natural resource personnel from state and federal agencies, and reviews of pertinent literature. Lists of the flora and fauna observed or expected to occur in the riparian and upland plant community types at the processing, disposal, and borrow pit sites are provided in Tables 2.1 through 2.5. The scientific names of species observed appear in these tables. Scientific names of species that were not observed on the site and do not appear in the tables are provided in the text.

\section{$2.1 \quad$ NATURITA PROCESSING SITE}

The vegetation at and near the processing site consists of three types: riparian, upland desert shrub, and bare ground, with early successional plant species in disturbed areas. The riparian vegetation along the San Miguel River grows in narrow bands along reaches of the river that are flanked by steep hillsides and broader expanses of relatively level ground where the river flows away from the hillsides (Figure 2.1). The vegetation in the narrow bands grows in three distinct zones: cottonwood/willow seedling zone, cottonwood/willow sapling zone, and mature cottonwood zone. The zone closest to the river is the cottonwood/ willow seedling plant community and consists of sandy and rocky bars that are flooded frequently. The dominant woody plant species are cottonwood and willow seedlings. Other commonly observed species are salt cedar, yellow sweet-clover, horsetail, sedges, and rushes. The cottonwood/willow sapling zone typically occurs on terraces above the river and is dominated by a dense growth of cottonwood saplings and willow. This zone is flooded much less frequently than the sandy bars, and a deep buildup of soil has taken place. Other woody plant species in this plant community are salt cedar, Russian olive, squawbush, and wild rose. The ground cover is very dense and dominated by grass. The upper zone is dominated by mature cottonwoods that typically grow up to the base of the hillsides and mark the beginning of the upland plant communities. The ages of these stands of cottonwood vary as indicated by size. Some stands are dominated by trees 25 to 35 feet ( $\mathrm{ft}$ ) ( 8 to 11 meters [m]) tall, while most trees in older stands are 45 to $55 \mathrm{ft}(14$ to $17 \mathrm{~m})$ tall. Within these stands, cottonwood is the only canopy species; willow, salt cedar, squawbush, and rabbitbrush are scattered in the understory. The ground cover is fairly dense, although not as dense as in the cottonwood/willow sapling zone, principally because of reduced penetration of light onto the forest floor.

The broader expanses of the riparian areas are an interspersion of riparian plant community types (Figure 2.1). Low-lying areas are dominated by willow. Drier ground is typically covered by cottonwood stands of various ages, with willow and other woody species in the understory and a ground cover of grass and herbs. Still drier areas are covered by the upper riparian shrub plant community. This plant community is typically open, and few cottonwoods are present. 
Table 2.1 Plant species observed in the area of the Naturita site, Colorado

\begin{tabular}{|c|c|c|c|}
\hline \multirow[b]{2}{*}{ Scientific name } & \multirow[b]{2}{*}{ Common name } & \multicolumn{2}{|c|}{ Habitat } \\
\hline & & Riparian & Upland \\
\hline \multicolumn{4}{|c|}{ TREES AND SHRUBS } \\
\hline Artemesia tridentata & big sagebrush & & $x$ \\
\hline Atriplex canescens & four-wing saltbush & & $x$ \\
\hline Atriplex sp. & saltbush & & $x$ \\
\hline Cercocarpus montanus & mountain mahogany & & $x$ \\
\hline Chrysothamnus nauseosus & golden rabbitbrush & $x$ & $x$ \\
\hline Chrysothamnus viscidiflorus & rabbitbrush & $x$ & $x$ \\
\hline Clematis ligusticifolia & western virgin's bower & $x$ & \\
\hline Elaeagnus angustifolia & Russian olive & $x$ & \\
\hline Ephedra sp. & Mormon tea & & $x$ \\
\hline Forestiera neomexicana & privet & $x$ & \\
\hline $\begin{array}{l}\text { Gutierrezia sarothrae } \\
\text { Juniperus sp. }\end{array}$ & $\begin{array}{l}\text { broom snakeweed } \\
\text { juniper }\end{array}$ & & $\begin{array}{l}x \\
x\end{array}$ \\
\hline Opuntia sp. & prickly pear & $\mathrm{X}$ & $x$ \\
\hline Pinus edulis & pinon pine & & $x$ \\
\hline Populus angustifolia & narrowleaf cottonwood & $x$ & \\
\hline Populus fremontii & Fremont cottonwood & $x$ & \\
\hline Quercus gambelii & Gambel's oak & & $x$ \\
\hline Rhus radicans & poison ivy & $x$ & \\
\hline Rhus fendleri & squawbush & $x$ & \\
\hline Rosa fendleri & Fendler rose & $x$ & \\
\hline Salix sp. & willow & $x$ & \\
\hline Salsola kali & Russian thistle & $x$ & $\mathrm{X}$ \\
\hline Sarcobatus vermiculatus & greasewood & $x$ & $x$ \\
\hline Shepherdia argentea & silver buffaloberry & $x$ & \\
\hline Tamarix parviflora & salt cedar & $\mathrm{x}$ & \\
\hline Yucca baccata & banana yucca & & $\mathrm{X}$ \\
\hline Yucca sp. & yucca & & $\mathrm{X}$ \\
\hline \multicolumn{4}{|c|}{ FORBS AND HERBS } \\
\hline Asclepias sp. & milkweed & & $x$ \\
\hline Astragalus sp: & milkvetch & & $x$ \\
\hline Castilleja sp. & paintbrush & & $\mathrm{x}$ \\
\hline Cirsium sp. & thistle & $x$ & $x$ \\
\hline Cordylanthus wrightii & birdbeak & & $x$ \\
\hline Equisetum arvense & common horsetail & $x$ & \\
\hline Eriogonum racemosum & red-root buckwheat & & $x$ \\
\hline Helianthus annuus & common sunflower & & $x$ \\
\hline Lactura ludoviciana & western lettuce & & $\mathrm{x}$ \\
\hline Leucelene ericoides & baby white aster & & $x$ \\
\hline
\end{tabular}


Table 2.1 Plant species observed in the area of the Naturita site, Colorado (Concluded)

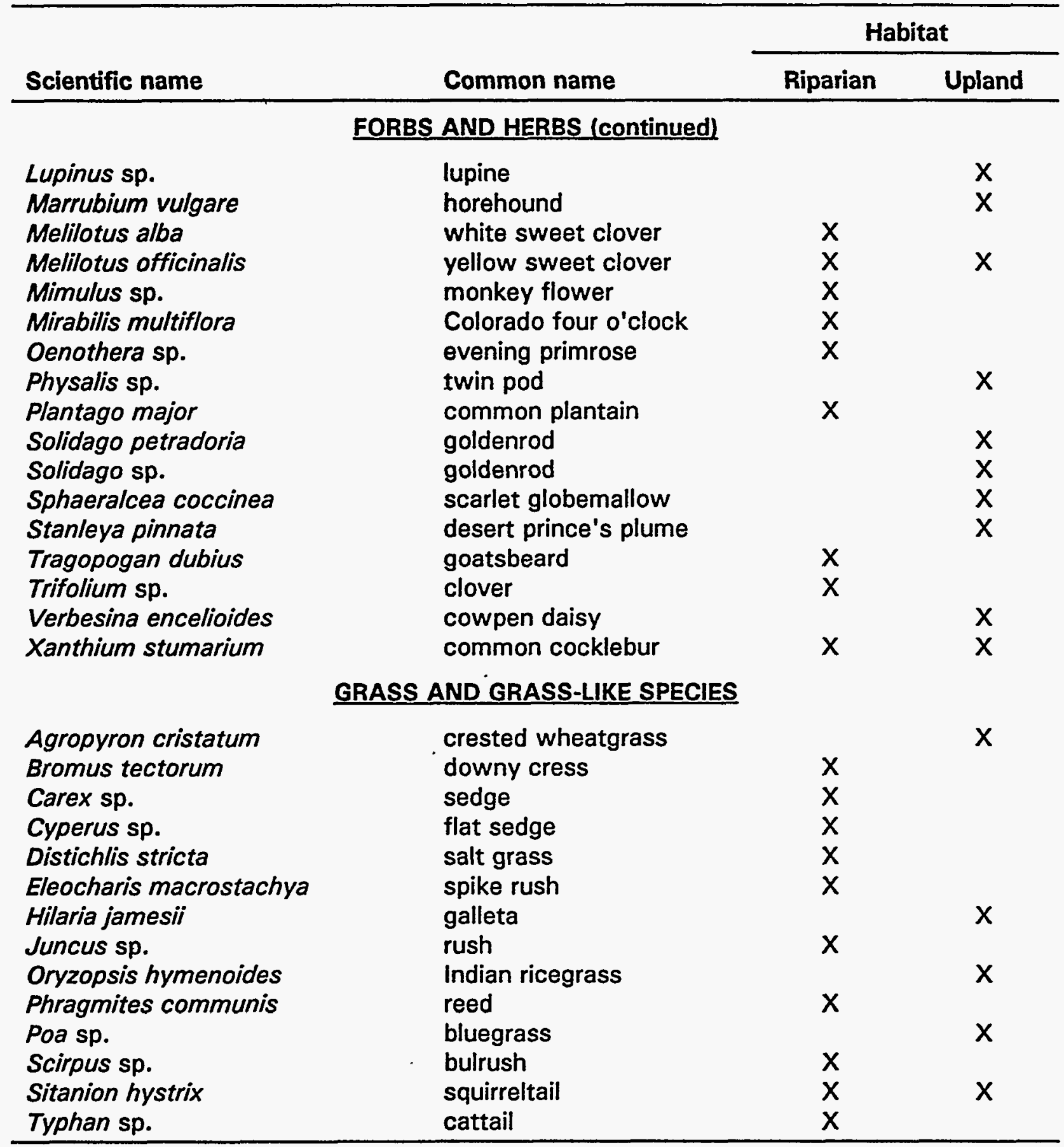

Ref. TAC, 1988, 1986; DOE, 1983. 
Table 2.2 Fish species recorded in the San Miguel River at the Naturita site, Colorado

\begin{tabular}{|c|c|}
\hline Scientific name & Common name \\
\hline $\begin{array}{l}\text { Salmo giarderneri } \\
\text { Salmo clarki } \\
\text { Rhinichthys osculus } \\
\text { Catostomus discobolus } \\
\text { Catostomus latipinnis } \\
\text { Cottus bairdi }\end{array}$ & $\begin{array}{l}\text { rainbow trout } \\
\text { cutthroat trout } \\
\text { speckled dace } \\
\text { bluehead sucker } \\
\text { flannelmouth sucker } \\
\text { mottled sculpin }\end{array}$ \\
\hline
\end{tabular}

Ref. CDOW, 1977.

Table 2.3 Amphibians and reptiles observed or expected to occur in the area of the Naturita site, Colorado

\begin{tabular}{|c|c|c|c|}
\hline \multirow[b]{2}{*}{ Scientific name } & \multirow[b]{2}{*}{ Common name } & \multicolumn{2}{|c|}{ Habitat } \\
\hline & & Riparian & Upland \\
\hline Ambystoma tigrinum & tiger salamander & $\mathrm{X}$ & $\mathrm{x}$ \\
\hline Scaphiopus multiplicatus & New Mexico spadefoot & & $x$ \\
\hline Bufo punctatus & red-spotted toad & & $x$ \\
\hline Bufo woodhousit & Woodhouse's toad & $\mathrm{X}$ & \\
\hline Rana pipiens & northern leopard frog & $x$ & \\
\hline Crotaphytus collaris & collared lizard & & $x$ \\
\hline Phrynosoma douglassii & short-horned lizard & & $x$ \\
\hline Sceloporus graciosus ${ }^{a}$ & sagebrush lizard & & $x$ \\
\hline Sceloporus undulatus ${ }^{a}$ & èstern fence lizard & $x$ & $x$ \\
\hline Urosaurus ornatus & tree lizard & & $x$ \\
\hline Uta stansburiana & side-blotched lizard & & $x$ \\
\hline Cnemidophorus tigris $^{\circ}$ & western whiptail & $x$ & \\
\hline Cnemidophorus velox ${ }^{\circ}$ & plateau striped whiptail & $x$ & $x$ \\
\hline Elaphe guttata & corn snake & $x$ & \\
\hline Masticophis taeniatus & striped whipsnake & & $x$ \\
\hline \multirow{3}{*}{$\begin{array}{l}\text { Pituophis melanoleucus } \\
\text { Thamnophis elegans }\end{array}$} & bull snake & $x$ & $x$ \\
\hline & western terrestrial & & \\
\hline & garter snake & $x$ & $x$ \\
\hline Crotalus viridis & western rattlesnake & $x$ & $x$ \\
\hline Opheodrys vernalis ${ }^{a}$ & smooth green snake & $x$ & \\
\hline
\end{tabular}

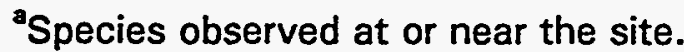

Ref. TAC, 1990, 1988, 1986; Hammerson, 1986; DOE, 1983. 
Table 2.4 Bird species observed in the area of the Naturita site, Colorado

\begin{tabular}{|c|c|c|c|}
\hline \multirow[b]{2}{*}{ Scientific name } & \multirow[b]{2}{*}{ Common name } & \multicolumn{2}{|c|}{ Habitat } \\
\hline & & Riparian & Upland \\
\hline Ardea herodias & great blue heron & $x$ & \\
\hline Branta camadensis & Canada goose & $x$ & \\
\hline Anas platyrhynchos & mallard & $x$ & \\
\hline Mergus merganser & common merganser & $x$ & \\
\hline Charadrius vociverus & killdeer & $x$ & \\
\hline Actitis macularia & spotted sandpiper & $x$ & \\
\hline Cathartes aura & turkey vulture & $\mathrm{x}$ & $x$ \\
\hline Aquila chysdetos & golden eagle & & $x$ \\
\hline Accipiter cooperij & Cooper's hawk & $X$ & $x$ \\
\hline Buteo jamaicensii & red-tailed hawk & $\mathrm{x}$ & $x$ \\
\hline Falco sparverius & American kestrel & $\mathrm{X}$ & $x$ \\
\hline Phasianus colchicus & ring-necked pheasant & $X$ & \\
\hline Columba livia & rock dove & $x$ & \\
\hline Zenaida macroura & mourning dove & $x$ & $x$ \\
\hline Chordeiles minor & common nighthawk & $x$ & $\mathrm{X}$ \\
\hline Aeronautes saxatalis & white-throated swift & $x$ & \\
\hline Ceryle alcyon & belted kingfisher & $x$ & \\
\hline Selasphorus platycercus & broad-tailed hummingbird & $x$ & \\
\hline Archilochus alexandri & black-chinned hummingbird & $x$ & \\
\hline Colaptes auratus & northern flicker & $x$ & \\
\hline Melanerpes lewis & Lewis woodpecker & $x$ & \\
\hline Sphyrapicus nuchalis & red-naped sapsucker & $x$ & \\
\hline Picoides villosus & hairy woodpecker & $X$ & \\
\hline Tyrannus verticalis & western kingbird & $\mathrm{X}$ & \\
\hline Myiarchus cinerascens & ash-throated flycatcher & $x$ & \\
\hline Contopus sordidulus & western wood pewee & $\mathrm{X}$ & \\
\hline Sayornis saya & Say's phoebe & $x$ & \\
\hline Empidonax wrightii & gray flycatcher & $x$ & \\
\hline Empidonax traillii & willow flycatcher & $\mathrm{X}$ & \\
\hline Eremophila alpestris & horned lark & & $x$ \\
\hline Tachycineta thalassina & violet-green swallow & $x$ & \\
\hline Stelgidopteryx serripennis & northern rough-winged & & \\
\hline & swallow & $x$ & \\
\hline Hirundo pyrrhonota & cliff swallow & $x$ & \\
\hline Hirundo rustica & barn swallow & $x$ & \\
\hline Gymnorhinus cyanocephalus & pinon jay & & $\mathrm{X}$ \\
\hline Aphelocoma coerulenscens & scrub jay & & $x$ \\
\hline Pica pica & black-billed magpie & $x$ & \\
\hline Corvus brachyrhynchos & American crow & $x$ & \\
\hline Corvus corax & common raven & & $X$ \\
\hline Parus inornatus & plain titmouse & $\mathrm{X}$ & \\
\hline Parus atricapillus & black-capped chickadee & $x$ & \\
\hline Troglodytes aedon & house wren & & $x$ \\
\hline Salpinctes obsoletus & rock wren & & $x$ \\
\hline
\end{tabular}


Table 2.4 Bird species observed in the area of the Naturita site, Colorado (Concluded)

\begin{tabular}{|c|c|c|c|}
\hline \multirow[b]{2}{*}{ Scientific name } & \multirow[b]{2}{*}{ Common name } & \multicolumn{2}{|c|}{ Habitat } \\
\hline & & Riparian & Upland \\
\hline Catherpes mexicanus & canyon wren & & $x$ \\
\hline Polioptila caerulea & blue-gray gnatcatcher & & $\mathrm{X}$ \\
\hline Regulus calendula & ruby-crowned kinglet & $\mathrm{X}$ & $x$ \\
\hline Sialia mexicana & western bluebird & & $\mathrm{x}$ \\
\hline Sialia currucoides & mountain bluebird & & $x$ \\
\hline Turdus migratorius & American robin & $x$ & \\
\hline Dumetella carolinensis & gray catbird & $x$ & \\
\hline Minus polyglottos & northern mockingbird & $x$ & $\mathrm{X}$ \\
\hline Sturnus vulgaris & European starling & $\mathrm{x}$ & \\
\hline Vireo vicinior & gray vireo & & $x$ \\
\hline Vireo solitarius & solitary vireo & $\mathrm{X}$ & $x$ \\
\hline Vireo gilvus & warbling vireo & $\mathrm{x}$ & \\
\hline Vermivora virginiae & Virginia's warber & & $\mathrm{x}$ \\
\hline Vermivora celata & orange-crowned warbler & $x$ & \\
\hline Dendroica coronata & yellow-rumped warbler & $x$ & \\
\hline Dendroica fusca & blackburnian warbler & $\mathrm{x}$ & \\
\hline Dendroica nigrescens & black-throated gray warbler & & $x$ \\
\hline Dendroica petechia & yellow warbler & $\mathrm{x}$ & \\
\hline Oporornis tolmlei & MacGillivay's warbler & $x$ & \\
\hline Geothlpis trichas & common yellow throat & $\mathrm{X}$ & \\
\hline Icteria virens & yellow-breasted chat & $x$ & \\
\hline Pheucticus melanocephalus & black-headed grosbeak & $\mathrm{x}$ & $x$ \\
\hline Guiraca caerulea & blue grosbeak & $x$ & \\
\hline Passerina amoena & lazuli bunting & $x$ & \\
\hline Pipilo erythrophthalmus & rufous-sided towhee & $x$ & $x$ \\
\hline Zonotrichia leucaphrys & white-crowned sparrow & $\mathrm{x}$ & $x$ \\
\hline Zonotrichia albicollis & white-throated sparrow & $\mathrm{x}$ & $x$ \\
\hline Chondestes grammacus & lark sparrow & $x$ & \\
\hline Amphispiza bilineata & black-throated sparrow & & $x$ \\
\hline Spizella passerina & chipping sparrow & & $x$ \\
\hline Passerculus sandwichensis & savannah sparrow & $\mathrm{X}$ & $x$ \\
\hline Melospiza melodia & song sparrow & $x$ & \\
\hline Juneo hyemalis & dark-eyed junco & $x$ & $x$ \\
\hline Sturnella neglecta & western meadowlark & $x$ & $x$ \\
\hline Agelaius phoeniceus & red-winged blackbird & $x$ & \\
\hline Euphagus cyanocephalus & Brewer's blackbird & $x$ & \\
\hline Molothrus after & brown-headed cowbird & $x$ & \\
\hline Quiscalus quiscula & common grackle & $x$ & \\
\hline Icterus galbula & northern oriole & $x$ & \\
\hline Carduelis tristis & American goldfinch & $x$ & \\
\hline Carduelis psaltria & lesser goldfinch & $x$ & \\
\hline Carpodacus mexicanus & house finch & $x$ & $x$ \\
\hline
\end{tabular}

Ref. TAC, 1995, 1994a, 1993, 1992, 1990, 1988, 1986; DOE, 1983. 
Table 2.5 Mammals observed or expected to occur in the area of the Naturita site, Colorado

\begin{tabular}{|c|c|c|c|}
\hline \multirow[b]{2}{*}{ Scientific name } & \multirow[b]{2}{*}{ Common name } & \multicolumn{2}{|c|}{ Habitat } \\
\hline & & Riparian & Upland \\
\hline Sylvilagus nuttallii & mountain cottontail & $x$ & \\
\hline Sylvilagus auduboni ${ }^{\circ}$ & desert cottontail & & $\mathrm{X}$ \\
\hline Lepus californicus ${ }^{a}$ & black-tailed jackrabbit & & $x$ \\
\hline Eutamias minimus ${ }^{\circ}$ & least chipmunk & & $x$ \\
\hline Ammospermophilus leucurus & $\begin{array}{l}\text { white-tailed antelope } \\
\text { ground squirrel }\end{array}$ & & $x$ \\
\hline Spermophilus richardsonii & Richardson's ground & & \\
\hline & squirrel & $\mathrm{X}$ & $x$ \\
\hline Spermophilus variegatus & rock squirrel & & $\mathrm{X}$ \\
\hline Cynomys leucurus ${ }^{\circ}$ & Gunnison prairie dog & & $\mathrm{X}$ \\
\hline Thomomys talpoides & northern pocket gopher & $x$ & $x$ \\
\hline Perognathus flavus & silky pocket mouse & & $x$ \\
\hline Dipodomys ordii & Ord's kangaroo rat & $\mathrm{x}$ & $x$ \\
\hline Castor canadensis ${ }^{a}$ & beaver & $x$ & \\
\hline Peromyscus crinitus & canyon mouse & & $x$ \\
\hline Peromyscus maniculatus & deer mouse & $x$ & $x$ \\
\hline Peromyscus truei & pinon mouse & & $x$ \\
\hline \multirow{2}{*}{ Onychomys leucogaster } & northern grasshopper & & \\
\hline & mouse & & $x$ \\
\hline Neotoma lepida & desert woodrat & & $x$ \\
\hline Ondatra zibethicus & muskrat & $x$ & \\
\hline Zapus princeps & western jumping mouse & $x$ & \\
\hline Erethizon dorsatum & porcupine & $x$ & $x$ \\
\hline Canis latrans ${ }^{\circ}$ & coyote & $\mathrm{X}$ & $x$ \\
\hline Urocyon cinereoargenteus & gray fox & $\mathrm{X}$ & $x$ \\
\hline Procyon lotor & raccoon & $x$ & $x$ \\
\hline Mustela frenata & long-tailed weasel & $x$ & $x$ \\
\hline Mustela vison & $\operatorname{mink}$ & $\mathrm{X}$ & \\
\hline Taxidea taxus & badger & $x$ & $x$ \\
\hline Spilogale gracilis ${ }^{a}$ & western spotted skunk & $\mathrm{X}$ & $x$ \\
\hline Mephitis mephitis & striped skunk & $\mathrm{x}$ & $x$ \\
\hline Felis rufus ${ }^{a}$ & bobcat & $x$ & $x$ \\
\hline Cervus elaphus ${ }^{\circ}$ & elk & & $x$ \\
\hline Odocoileus hemionus ${ }^{a}$ & mule deer & $x$ & $x$ \\
\hline
\end{tabular}

'Species or species' sign observed at or near the site.

Ref. TAC, 1990, 1988, 1986; DOE, 1983; Bernard and Brown, 1978. 


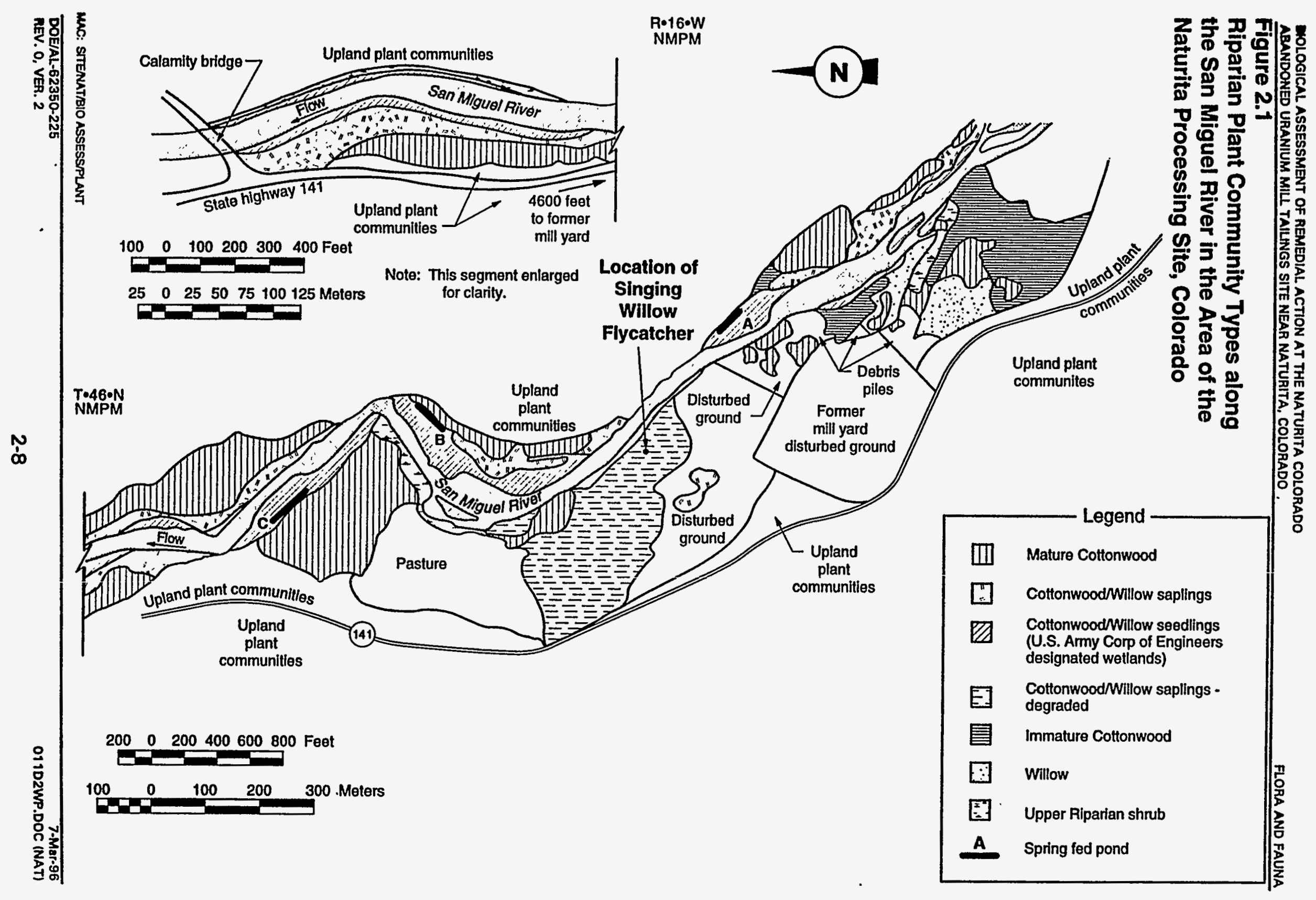


Riparian shrubs such as willow and squawbush and more upland plant species such as rabbitbrush and big sagebrush grow in fairly dense stands in this plant community. As in most of the riparian areas, there is a dense ground cover of grasses and herbs.

The upland desert shrub plant community occurs in small elevated areas along the river between the pockets of riparian vegetation. Common shrub species observed are greasewood, big sagebrush, squawbush, rabbitbrush, saltbush, yucca, prickly pear cactus, and Mormon tea. Widely scattered juniper, pinon pine, and Gambel's oak are also in this area. The ground cover is fairly dense and is dominated by grass and herbs.

Land areas have been disturbed in the mill yard and former tailings area. Much of the mill yard is flat, hard-packed gravel with little, if any, soil. As a result, there is much bare ground with very widely dispersed, early successional species such as Russian thistle and white sweet clover. Rabbitbrush is widely scattered in this area. Sloping areas within the mill yard have remnants of native vegetation; the plant species observed are similar to those observed in the upland vegetation growing between the pockets of riparian vegetation along the river. The eastern part of the former tailings area is rocky and largely devoid of vegetation. A dense growth of cottonwood saplings and young willows and salt cedars has developed in the western one-half of this area. Ground cover includes various species of grass and herbaceous species, including goldenrod, poison ivy, and sweet clover.

Bird surveys in the riparian habitats along the San Miguel River were conducted principally during the nesting season. Sixty-nine species were recorded. Five nesting bird censuses were taken over a 9-year period along the San Miguel River from Calamity Bridge upriver to the processing site (Table 2.6). These censuses showed the yellow warbler as the most common species. This warbler frequented all riparian habitat types. The spotted sandpiper was also common and was most often seen along the river. The western wood-pewee, northern oriole, and warbling vireo were frequently heard singing in the mature cottonwood stands. Nesting birds indicative of the shrubby riparian habitat were the yellow-breasted chat and rufous-sided towhee. The great-blue heron was occasionally seen fishing in the river but is not known to nest in the site area. Occasional waterfowl, including Canada geese, mallard, and common merganser, were observed on or flying up and down the river; one mallard brood was heard calling from a dense stand of willow in 1986. The San Miguel River constitutes marginal nesting habitat for waterfowl because of the lack of brood escape cover, especially when the river is low. Nest sites for birds of prey have not been observed along the river, but the prairie falcon (Falco mexicanus) and golden eagle (Aquila chrysaetos) could use the area for foraging. The common barn owl (Tyto alba), long-eared owl (Asio otus), great horned owl (Bubo virginianus), western screech owl (Otus kennicottin), and burrowing owl (Athene cunicularial could also occur in the area. Large numbers (up to 22) of turkey vultures have used a stand of mature cottonwoods across the river from the processing site as a roosting site for a number of years. 
Table 2.6 Nesting birds recorded from the riparian zone along a 1.3-mi $(2.1-\mathrm{km})$ stretch of the San Miguel River near the Naturita, Colorado, UMTRA Project site

\begin{tabular}{|c|c|c|c|c|c|c|}
\hline \multirow[b]{2}{*}{ Species } & \multicolumn{5}{|c|}{ Year } & \multirow[b]{2}{*}{ Average } \\
\hline & 1986 & 1990 & 1991 & 1994 & 1995 & \\
\hline Yellow warbler & 8 & 13 & 13 & 11 & 16 & 12 \\
\hline Spotted sandpiper & 3 & 5 & 8 & 4 & 7 & 5 \\
\hline Western wood pewee & 1 & 6 & 7 & 3 & 8 & 5 \\
\hline Yellow-breasted chat & 2 & 0 & 9 & 10 & 6 & 5 \\
\hline Brown-headed cowbird & 2 & 5 & 6 & 3 & 5 & 4 \\
\hline Warbling vireo & 3 & 6 & 0 & 2 & 8 & 4 \\
\hline Northern oriole & 2 & 4 & 5 & 1 & 1 & 3 \\
\hline House finch & 0 & 5 & 6 & 0 & 5 & 3 \\
\hline Western kingbird & 4 & 3 & 3 & 2 & 2 & 3 \\
\hline American robin & 4 & 1 & 0 & 4 & 4 & 3 \\
\hline Rufous-sided towhee & 2 & 1 & 1 & 6 & 4 & 3 \\
\hline Solitary vireo & 0 & 3 & 4 & 1 & 1 & 2 \\
\hline Mourning dove & 1 & 1 & 3 & 2 & 2 & 2 \\
\hline Black-billed magpie & 1 & 2 & 2 & 0 & 0 & 1 \\
\hline Black-headed grosbeak & 1 & 2 & 2 & 1 & 1 & 1 \\
\hline American starling & 0 & 4 & 1 & 0 & 0 & 1 \\
\hline Lark sparrow & 1 & 3 & 0 & 0 & 0 & 1 \\
\hline American crow & 0 & 2 & 2 & 0 & 2 & 1 \\
\hline American goldfinch & 0 & 4 & 0 & 0 & 0 & 1 \\
\hline Lazuli bunting & 3 & 0 & 0 & 1 & 0 & 1 \\
\hline Blue grosbeak & 0 & 0 & 3 & 4 & 0 & 1 \\
\hline Mallard & 1 & 0 & 1 & 0 & 1 & 1 \\
\hline Northern flicker & 1 & 1 & 0 & 2 & 1 & 1 \\
\hline Lesser goldfinch & 0 & 0 & 1 & 0 & 2 & 1 \\
\hline Willow flycatcher & 2 & 0 & 0 & 0 & 0 & $<0.5$ \\
\hline Red-winged blackbird & 2 & 0 & 0 & 0 & 0 & $<0.5$ \\
\hline Ash-throated flycatcher & 0 & 0 & 2 & 0 & 0 & $<0.5$ \\
\hline Killdeer & 1 & 0 & 0 & 0 & 0 & $<0.5$ \\
\hline American kestrel & 0 & 0 & 1 & 0 & 0 & $<0.5$ \\
\hline Belted kingfisher & 0 & 0 & 1 & 0 & 0 & $<0.5$ \\
\hline Broad-tailed hummingbird & 0 & 0 & 1 & 0 & 0 & $<0.5$ \\
\hline Black-chinned hummingbird & 0 & 0 & 1 & 1 & 0 & $<0.5$ \\
\hline Blue-gray gnatcatcher & 0 & 0 & 0 & 0 & 1 & $<0.5$ \\
\hline Say's phoebe & 0 & 0 & 0 & 1 & 0 & $<0.5$ \\
\hline Common merganser & 0 & 0 & 0 & 2 & 0 & $<0.5$ \\
\hline Cliff swallow & $\mathrm{x}$ & $\mathrm{x}$ & $\mathrm{x}$ & $x$ & $\mathrm{x}$ & $\mathrm{x}$ \\
\hline Total & 44 & 63 & 83 & 61 & 77 & 65 \\
\hline
\end{tabular}

'Nesting colony under Calamity Bridge.

Ref. TAC, 1995, 1994a, 1991, 1990, 1986. 
At least 19 species of mammals may occur in the riparian habitat along the San Miguel River. Beaver signs (droppings) were observed along the river. In 1986, there was much fresh beaver sign, and small beaver dams had been constructed in the drainages that run through the dense growth of cottonwoods in the former tailings area. Observations in 1988 revealed very little fresh beaver sign. Mule deer were observed along the river, and their sign was common. This area is likely a mule deer winter range but not a critical winter range. There are also year-round resident deer in the area.

Limited fish sampling in the San Miguel River resulted in six species being recorded (Table 2.2). The flannelmouth sucker and rainbow trout were the most common species collected.

\subsection{UPPER BURBANK QUARRY, URAVAN, DISPOSAL SITE AND UPPER CLUB MESA} BORROW SITE

The Uravan, Colorado, site is in Section 4, Township (T) 47 North (N), Range (R) 17 West (W), and Sections 28, 29, 33, and 34, T48N, R17W. The Uravan site is approximately $13 \mathrm{mi}(21 \mathrm{~km})$ northwest of the Naturita processing site via Colorado State Highway 141 (Figure 1.1). The disposal site is at the Upper Burbank Quarry and the borrow site is the Upper Club Mesa borrow site (Figure 2.2). Both of these facilities are located at the Uravan site and are on the Club Mesa, approximately $400 \mathrm{ft}(122 \mathrm{~m})$ above the San Miguel River. The Uravan site is currently licensed for the disposal of radioactive materials (Colorado Radioactive Material License No. 660-02) by the Colorado Department of Public Health and Environment (CDPHE)/Radiation Control Division (RCD). The site is also a Superfund site and is being reclaimed under the Comprehensive Environmental Response, Compensation, and Liability Act (CERCLA) and a court decree between the site owner and the state of Colorado. Since operations began at the Uravan facility in the 1950 s, over 10 million tons 19.1 million metric tons) of tailings, millions of gallons of waste liquid raffinate, raffinate crystal residue, and other milling wastes containing radioactive materials, metals, and other inorganic contaminants have been produced and are scheduled to be placed in repositories currently under construction at the site.

The Upper Burbank Quarry is an existing facility that has been excavated out of the hillside. The ground at and near this facility has been highly disturbed and no natural plant communities remain. The Upper Club Mesa borrow site is also an existing facility that has been excavated out of the hillside. Here again, no natural plant communities exist at this location. However, this borrow site may have to be enlarged, which may result in the excavation of a pinon-juniper plant community.

\section{$2.3 \quad$ HAUL ROADS}

The transportation of the contaminated material at the Naturita processing site to the disposal site will occur along existing roads; no new road construction nor widening is anticipated. 


\section{Figure 2.2}

Uravan Disposal Facility (Upper Burbank Quarry) and Upper Club Mesa

Borrow Site at the Uravan Site in Montrose County, Colorado

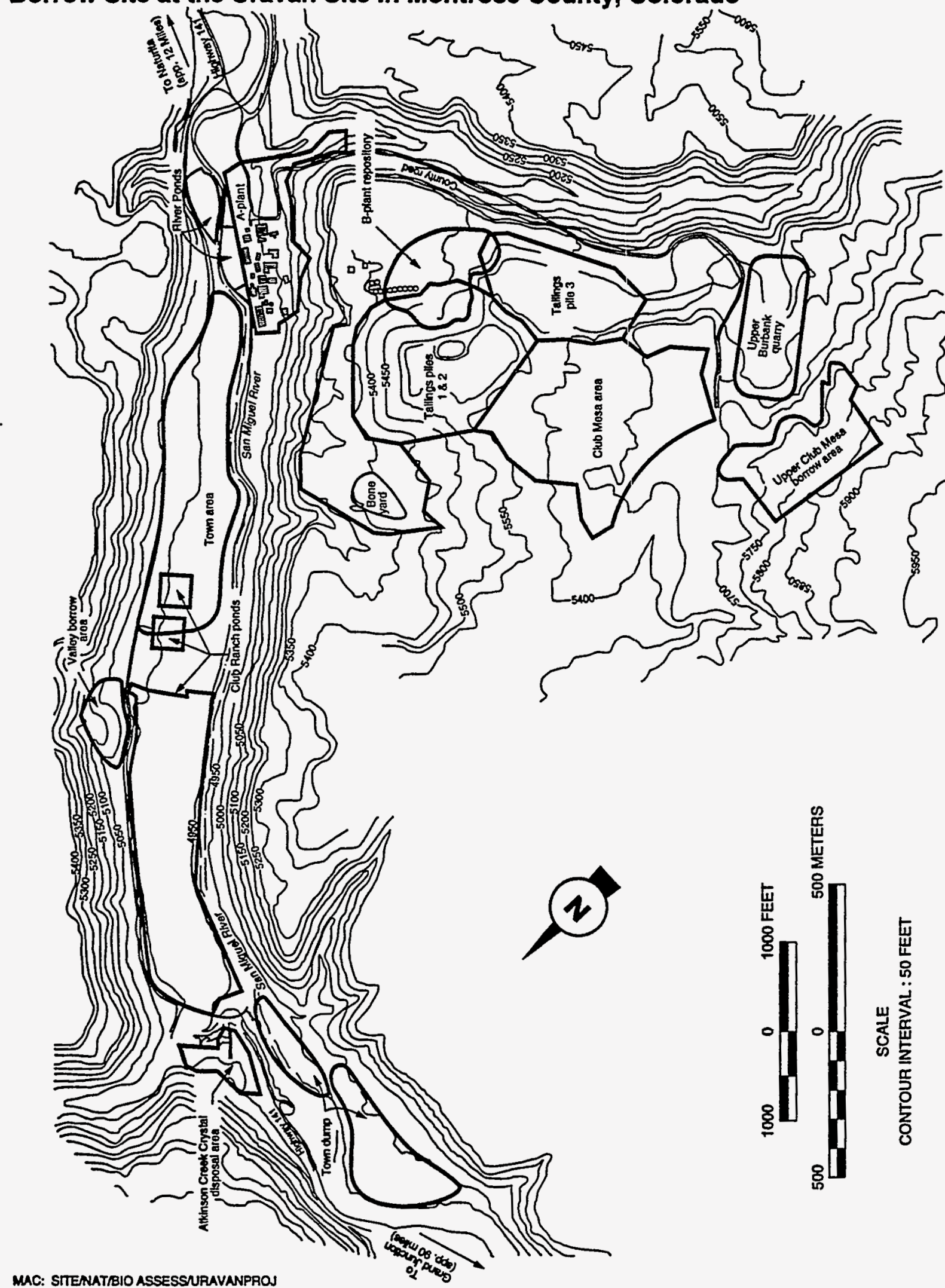


The contaminated material will be hauled approximately $11 \mathrm{mi}(18 \mathrm{~km})$ from the Naturita site to County Road EE-22 along State Highway 141 and then $2 \mathrm{mi}$ (3 $\mathrm{km}$ ) up a county road to the disposal site (see Figures 1.1 and 2.2). State Highway 141 follows the San Miguel River and traverses both upland areas above the river and riparian areas near the river. The upland areas are dominated by big sage brush and pinon-juniper plant communities. Near the river, the road runs near mature cottonwood stands and areas dominated by willows and other riparian shrubs. The major area of riparian plant communities along the river is the San Miguel at Tabeguach Creek Preserve near Uravan; this area is administered by The Nature Conservancy. It is estimated that approximately 4 $\mathrm{mi}(6 \mathrm{~km})$ of the $11-\mathrm{mi}(8-\mathrm{km})$ haul route along State Highway 141 passes next to riparian plant communities along the river (TAC, 1994b); the remainder passes through upland plant communities away from the river.

County Road EE-22 rises quickly above the river valley and traverses very little of the river's riparian zone.

\section{$2.4 \quad$ PROPOSED ACTION}

The proposed action is described in detail in the Naturita remedial action plan (DOE, 1995). The RRM will be moved from the Naturita processing site to the Uravan site, where the RRM will be stabilized in the Upper Burbank Quarry. Disposal at this site will be consistent with the U.S. Environmental Protection Agency (EPA) standards for active uranium processing sites (40 CFR Part 192) and other appropriate authorizations and will be performed in accordance with a disposal plan prepared by the owner and operator of the site and approved by the CDPHE. The trucks hauling the Naturita RRM will proceed to the disposal site and be unloaded. The haulage trucks will then be decontaminated at a location within the Uravan site before returning to the Naturita processing site. Remedial action will take approximately 18 months, with one winter shutdown period of 4 months (December through March). The first year will consist of preparing the necessary work areas and facilities and hauling contaminated material. After the winter shutdown, the remaining RRM will be relocated to the Uravan site, the disposal cell will be completed, and the Naturita site will be restored.

\section{$2.5 \quad$ IMPACTS TO FLORA AND FAUNA}

Flora and fauna will be affected directly and indirectly by remedial action. Direct effects will include the loss of habitat, loss of less mobile wildlife species, and displacement of other wildlife species. Indirect effects will arise from increased fugitive dust, noise levels, and human activity. The duration of the direct effects will depend on the level of restoration, and indirect effects will last for the duration of the remedial action or less.

Remedial action at the Naturita site will disturb approximately 87 acres (ac) (35 hectares [hal) consisting of riparian vegetation (47 ac [19 ha]) and previously disturbed ground with little vegetation (40 ac [16 ha]). The riparian plant 
communities along the San Miguel River are productive in terms of flora and fauna and are relatively scarce in the region. Consultation with the U.S. Army Corps of Engineers (USACE) indicated that 4 ac ( 2 ha) of cottonwood/willow seedlings along the San Miguel River meet the USACE definition of a wetland. The remaining riparian plant communities along the river do not meet the USACE definition of a wetland because they lack the proper hydrological conditions (Jacobsen, 1992).

As indicated above, the Upper Burbank Quarry and Upper Club Mesa borrow sites are in areas of highly disturbed land so the use of these facilities would not result in the disturbance of natural plant communities. In addition, the haul will take place along existing roads so no land will need to be cleared for roads.

The clearing of vegetation from the riparian areas would temporarily reduce or prohibit wildlife use. The duration of this effect would depend on the level of restoration undertaken. Remedial action would remove not only the vegetation but also some of the soil. This soil could not be stockpiled because it is contaminated and must be incorporated into the disposal cell. Research has shown that the rate of vegetation recovery on mine spoil varies widely, depending on the restoration methods employed (Aldon, 1981; Wagner et al., 1978). The hypothetical maximum effect would result from no restoration except recontouring, which would result in the recovery of the biotic community on land devoid of topsoil. In this case, primary succession (i.e., a sequence of plant communities developing in a newly exposed habitat devoid of life [Ricklefs, 1979]) would take place and recovery could take years, especially in the dryer areas away from the river (Evans et al., 1978). However, recent experience has shown that procedures such as fertilization, use of proper seed mixtures, pole planting in riparian habitats, and protection from grazing can enhance successful revegetation (Richardson et al., 1986; Swenson and Mullins, 1985; York, 1985). Prior to any surface disturbance, plans for restoring excavated areas would be developed by the remedial action contractor and the DOE in consultation with the appropriate regulatory agency or other authority. In general, these plans would involve backfilling, recontouring, and revegetation. Effects would be mitigated by performing restoration as soon as possible after the completion of surface-disturbing activities.

The effects on game species at the Naturita site are expected to be minimal. The mule deer is a year-round resident at the Naturita processing site; however, habitat features that would be disturbed during remedial action, such as critical winter range, do not occur at or near the site. Large numbers of mule deer cross State Highway 141 between Naturita and Uravan in March and April to reach alfalfa fields between the road and river. The Colorado Division of Wildlife recommends that speed limits and deer crossing signs be in place at this time of year (Arndt, 1994).

A limited amount of waterfowl production occurs along the San Miguel River in the site area, but remedial action activities would be expected to have a minimal effect on waterfowl production. The effects on birds of prey at the site would 
also be expected to be minimal to nonexistent. No large hawks are known to nest in the cottonwood stands that may be affected. The kestrel and certain species of small owls may nest in these areas and may be affected.

An analysis of possible effects on threatened and endangered species is presented in Section 3.0 of this biological assessment. This analysis indicates that there would be no direct effects on threatened and endangered species except possibly on the southwestern willow flycatcher (Empidonax traillii extimus). The southwestern willow flycatcher was heard calling along the San Miguel River in 1986; however, this species was not observed or heard along the San Miguel River in the Naturita site area from 1990 through 1995. It was therefore determined that the southwestern willow flycatcher does not currently nest in the areas that could be affected by remedial action. Surveys for this bird species will be conducted again in 1996 and 1997. If these surveys reveal that the southwestern willow flycatcher nests in areas that would be affected by the remedial action, a mitigation plan will be prepared in consultation with the FWS. One possible mitigation measure would be to limit remedial action activities in the habitat of the southwestern willow flycatcher.

Water from the San Miguel River will be used for the remedial action (e.g., for dust control and equipment decontamination). This water use will result in a net depletion of water in the upper Colorado River basin and "may affect" determination for the Colorado squawfish (Ptychocheilus lucius), humpback chub (Gila cypha), bonytail chub (Gila elegans), and razorback sucker (Xyrauchen texanus). In addition, this depletion will adversely affect the critical habitat of these fish species. These determinations will require formal conferencing with the FWS and may result in the payment of a dollar amount per acre-foot of the average annual water withdrawal for the remedial action. It is estimated that remedial action will require an average annual water withdrawal of 76 ac- $\mathrm{ft}$ from the San Miguel River. Based on a letter received from the FWS, it is assumed that the water depletion fee will be waived because the average annual water withdrawal will be less than 100 ac-ft (Rose, 1995). 



\subsection{THREATENED AND ENDANGERED SPECIES}

This section describes the status of the threatened and endangered species that may occur in the study area. The federally listed threatened and endangered species are the blackfooted ferret (Mustela nigripes), bald eagle (Haliaeetus leucocephalus), peregrine falcon (Falco peregrinus), southwestern willow flycatcher, Colorado squawfish, bonytail chub, humpback chub, razorback sucker, and Uinta Basin hookless cactus (Sclerocactus glaucus). The FWS has redefined its list of federal candidate species and consequently no candidate species occur in the project area (see Appendix A).

\subsection{MAMMALS}

\section{Black-footed ferret}

The black-footed ferret is also listed as endangered by the state of Colorado. No critical habitat has been designated. The ferret, primarily nocturnal, is closely associated with prairie dogs throughout its range. The ferret preys on prairie dogs and uses the prairie dog burrows as shelter and den sites. Because of this close association, all active prairie dog colonies are considered potential black-footed ferret habitat (Clark et al., 1984). The potential for the black-footed ferret to occur at and adjacent to the Naturita processing site is low (Carruthers, 1986). No active prairie dog towns were observed during multiple surveys of the Naturita site (TAC, 1995, 1994a, 1993, 1992, 1990, 1988, 1986). Prairie dog towns would not occur at the Upper Burbank Quarry and Upper Club Mesa borrow site because the land is highly disturbed. Prairie dog towns would also not be expected in the habitat around these sites because it is a pinon-juniper plant community. Therefore, since there is no potential habitat for the species in the site area, remedial action at the Naturita site will not affect the black-footed ferret.

\section{$3.2 \quad$ BIRDS}

\section{Bald eagle}

The bald eagle is also listed as endangered by the state of Colorado. No critical habitat has been designated. The eagle is generally associated with river habitat where suitable perches and viable fisheries are available; large cottonwood trees are used for perching or roosting sites. The eagle feeds mainly on fish; however, carrion, waterfowl, and rabbits may also be consumed, especially during the winter (Woodward-Clyde, 1983). The bald eagle is a common winter resident locally along major rivers and is a rare breeder in western Colorado (CDM and Bio/West, 1983). It is not known to nest along the San Miguel River but does hunt along the river during the winter. In addition, a raptor survey conducted by the FWS in the areas of potential impact did not reveal any bald eagle nests (Opdycke, 1987). Although bald eagles have been seen perched in the cottonwoods in the riparian habitat, there are no known, regularly used roost sites along the river in the area of the Naturita processing site. The bald eagle 
density is generally low (approximately six) along the river between Naturita and Uravan, and use of the upland site areas is sporadic (Arndt, 1994; Welch, 1993; Sherman, 1987; Carruthers, 1986). There are two winter concentration areas near the processing site. One is along the San Miguel River, 5 to $6 \mathrm{mi}$ (8 to 10 $\mathrm{km}$ ) northeast of the site, and the other is along the Dry Creek basin, 5 to $6 \mathrm{mi}$ $(8$ to $10 \mathrm{~km}$ ) south of the site (Welch, 1993). The remedial action activities would not affect these two winter concentration areas. Given that winter bald eagle use along the San Miguel River is light in the site area, there will be a 4-month winter shutdown of the remedial action, there are no winter perch or roost sites at or near the site, and there are numerous cottonwood stands along the river, remedial action activities are not expected to affect the bald eagle.

\section{Peregrine falcon}

Historically, the peregrine falcon nested in at least 27 locations in Colorado. By 1972, there were eight known nesting locations, none of which produced any young. This drastic reduction was due to the widespread use of dichlorodiphenylthrichloroethane (DDT) (Scott, 1985). The peregrine falcon recovery program began in 1975. As of 1987, the total number of breeding pairs had increased to $23 ; 22$ pairs successfully fledged young (CDOW, 1988).

The peregrine falcon nests 8 to $10 \mathrm{mi}(12$ to $15 \mathrm{~km})$ from the Uravan site along the Dolores River (Leachman, 1996). Remedial action activities would not have a direct impact on nesting peregrines; however, peregrine falcons may travel long distances from the aerie to secure food. The Uravan site is within the feeding range of nesting peregrine falcons, which has been estimated to be up to $10 \mathrm{mi}(16 \mathrm{~km})$ (CDOW, 1978). However, preferred feeding areas are riparian habitat such as occur along the San Miguel River at the Uravan site (FWS, 1984) and remedial action activities at the Uravan site would not take place within the San Miguel River riparian zone. Remedial action would take place in the riparian zone of the river at the Naturita processing site. However, this site is well over $20 \mathrm{mi}(32 \mathrm{~km})$ from the peregrine falcon aerie and is well outside the feeding range of this species. Therefore, remedial action is expected to have no effect on the peregrine falcon's nesting along the Dolores River.

\section{Southwestern willow flycatcher}

The willow flycatcher is widely distributed in the United States. There are four subspecies of the willow flycatcher, and the southwestern willow flycatcher occurs in the southwestern United States. The northern boundary of the range of the southwestern willow flycatcher has been determined to be southern Colorado; the Naturita site is within the boundary of the subspecies. Populations of the southwestern willow flycatcher have declined precipitously due, primarily, to habitat destruction, and 500 to 1000 pairs probably exist in the wild (Unitt, 1987).

The southwestern willow flycatcher generally nests in willows; in recent years, they have begun to nest in salt cedars. The preferred habitat in the southwest is 
riparian habitat along bodies of water, such as that which occurs along the San Miguel River (Unitt, 1987). Two male willow flycatchers were heard calling repeatedly at the Naturita site in 1986 (TAC, 1986). These birds were singing in the dense cottonwoods and willows that grow in the western part of the former tailings area (see Figure 2.1). It is possible that these birds were nesting because the willow flycatcher migration was essentially complete and migrating willow flycatchers rarely sing (Unitt, 1987). These observations took place before the southwestern willow flycatcher was designated as an endangered species. Field surveys for this species were conducted in June of 1990, 1991, 1993, 1994, and 1995 along the San Miguel River (TAC, 1995, 1994a, 1993, $1991,1990)$. These surveys included approximately $3 \mathrm{mi}(5 \mathrm{~km})$ of the San Miguel River, upstream and downstream of the Naturita site. In 1995, the study was expanded to include riparian habitat along the river in areas where State Highway 141 runs close to the river. These areas include The Nature Conservancy San Miguel River Preserve near Uravan. The willow flycatcher was reported at this preserve during the 1994 nesting season (Ireland, 1995). The southwestern willow flycatcher was neither heard nor observed in the area of the Naturita site nor in riparian areas near State Highway 141 in 1995. In addition, the willow flycatcher was not recorded during a 1995 survey of The Nature Conservancy land near Uravan conducted by Bureau of land Management biologists (Ferguson, 1996).

Based on the surveys for the southwestern willow flycatcher from 1990 through 1995, it is determined that this bird species does not currently nest along the San Miguel River at or near the Naturita processing site nor in areas near the State Highway 141 haul road and that remedial action will not affect this species. However, because potential habitat for this species occurs in the areas that would be affected by remedial action and it has been recorded in the area previously, surveys for this species will be conducted in 1996 and 1997; remedial action is scheduled to be completed in 1997. If these surveys determine that the southwestern willow flycatcher nests in areas that will be disturbed during remedial action, formal conferencing with the FWS will be initiated, and a mitigation plan will be prepared. This plan may include such measures as postponing or suspending remedial action in the area of concern until after the nesting season or trapping the birds and moving them.

\subsection{FISH}

\section{Colorado squawfish}

The Colorado squawfish is also listed as endangered by the state of Colorado. This fish is the largest minnow in North America. Its historical range includes the Colorado River and all of the larger tributaries from Wyoming to the Gulf of California, such as the San Miguel River. The Colorado squawfish is now rare and limited to the upper Colorado River basin (Valdez et al., 1982). Although the Colorado squawfish historically occurred in the San Miguel River, its relative abundance was rare, as reported by Nolting (1957). Currently, the squawfish 
does not occur in the San Miguel River, and it is unlikely that this river meets the habitat requirements of this fish (Carruthers, 1986).

\section{Bonytail and humpback chubs}

The bonytail and humpback chubs are also listed as endangered by the state of Colorado. These fishes were historically distributed throughout the Colorado River basin in main river channels and larger tributaries. The bonytail chub was most common in the open river area of large river channels, while the humpback chub was restricted to swift, deep water areas, mainly in canyons. Historically, the bonytail chub was reported to be abundant in the San Miguel River (Nolting, 1957). The humpback chub may have also occurred in the San Miguel River. Currently, neither chub species occurs in the San Miguel River, and it is unlikely that the river meets the habitat requirements of these fishes (Carruthers, 1986).

\section{Razorback sucker}

The razorback sucker originally occupied $1500 \mathrm{mi}(2414 \mathrm{~km})$ of the Colorado River system. Its current distribution is limited to $600 \mathrm{mi}(965 \mathrm{~km})$, mostly in the upper river basin. All specimens of this fish collected in the upper Colorado River were adults, which suggests a low reproductive rate. Although the habitat preference of this species has not been fully evaluated due to the small number of observations, it appears to prefer backwaters and gravel pits with little or no flow and silt bottoms (Valdez et al., 1982). The razorback sucker may have occurred in the San Miguel River. However, this river is not currently occupied by the razorback sucker, and it is unlikely that the river meets the habitat requirements of this fish (Carruthers, 1986).

\section{Impacts to endangered fish}

Endangered fish species do not occur in the San Miguel River, so remedial action will not have a direct impact on these species. However, remedial action at the Naturita site may have an indirect impact on the endangered fish species. The FWS determined that an upper Colorado basin-wide (which includes the San Miguel River) jeopardy situation has existed since 1978 for the four fish species discussed above (FWS, 1987). Depletion of water within the basin, which includes water required for remedial action, would have a negative impact on these species and would result in a "may affect" determination by the FWS. This determination requires the initiation of formal conferencing with the FWS under the Endangered Species Act. According to the "Recovery Implementation Program for Endangered Fish Species in the Upper Colorado River Basin" (FWS, 1987), water depletion subject to a "may affect" determination would require a one-time contribution to the FWS of a dollar amount per acre-foot of water used, based on the average annual water depletion caused by a project. Water from the San Miguel River will be used for the remedial action (e.g., for dust control and equipment decontamination), and it is estimated that the average annual water requirement for remedial action at the Naturita site will be 76 ac-ft. Based on a letter received from the FWS, it is assumed that the water 
depletion fee will be waived because the average annual water withdrawal will be less than 100 ac-ft (Rose, 1995)

The FWS has designated $2096 \mathrm{mi}(3369 \mathrm{~km})$ of the Colorado River and its tributaries as critical habitat for the endangered fish species. Therefore, the withdrawal of water from the San Miguel River for the remedial action will be "an adverse modification of this critical habitat" that will require formal conferencing with the FWS (refer to the FWS letter dated 20 April 1993, in Appendix A). However, the FWS has determined that the endangered fish recovery program has made sufficient progress so water depletion fees for projects that use an average annual 100 ac-ft of water or less will be waived in relation to the endangered fish critical habitat (Rose, 1995). Since the average annual water depletion for the Naturita project is estimated to be 76 ac-ft, a onetime payment to the FWS on mitigation for the adverse modification of critical habitat will not be required.

\section{$3.4 \quad$ PLANTS}

\section{Uinta Basin hookless cactus}

The Uinta Basin hookless cactus is a threatened species and occurs in two disjunct populations: one from the Uinta Basin in Utah and the other from Mesa and Delta counties in Colorado (Heil and Porter, 1987). This species has taxonomic problems and some authorities believe it does not represent a distinct species. However, Heil and Porter (1987) used the hierarchical cluster analysis to compare characteristics of this species with the closely related Sclerocactus parviflorus and determined that the Uinta Basin hookless cactus should continue to be considered a distinct species.

The Uinta Basin hookless cactus is generally found growing on south, southeast, and southwest exposures. It typically grows on gravelly soils on the tops or slopes of hills and rarely on level ground between hills. This species is generally restricted to Mancos, Duchesne, Green River, and Wasatch Formations. Dominant plant species that occur with this cactus are mat saltbush, shadscale, Welsh saltbush, greasewood, and jointfir (Ephedra torreyana) (Heil and Porter, 1987).

The Uinta Basin hookless cactus probably does not occur in the Naturita and Uravan areas because these sites are outside of its reported range. Experts for this species also concur that it probably does not occur in the Naturita and Uravan areas (Ferguson, 1996; Heil, 1996). In addition, appropriate desert shrub habitat does not occur at or near areas that would be disturbed during remedial action. For these reasons, Naturita site remedial action would not affect this threatened species. 



\subsection{LIST OF CONTRIBUTORS}

The following individuals contributed to the preparation of this report.

\begin{tabular}{ll}
\hline Name & Contribution \\
\hline C. Burt & Document coordinator \\
C. Burt & Primary author \\
E. Artiglia, S. Cox, R. Neri Zagal, & Document review \\
W. Woodworth & \\
J. Jones & Editing \\
K. DeGruyter & Graphics design \\
L. Sanchez & Text processing \\
\hline
\end{tabular}




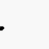




\subsection{REFERENCES}

Aldon, E. F., 1981. "Long-Term Plant Survival and Density Data from Reclaimed Southwestern Coal Mine Spoils," in The Great Basin Naturalist, Vol. 51, No. 3, pp. 271-273.

Arndt, R., 1994. Colorado Division of Wildlife, Nucla Colorado, personal communication with C. Burt, Jacobs Engineering Group Inc., UPDCC File Location No. 17.15.1.4, Albuquerque, New Mexico, August 30, 1994.

Bernard, S. R., and K. F. Brown, 1978. "Distribution of Mammals, Reptiles, and Amphibians by BLM Physiographic Regions and A. W. Kuchler's Associations for the Eleven Western States," U.S. Department of the Interior, Bureau of Land Management, Denver, Colorado.

Carruthers, R. V., 1986. Uncompahgre Basin Resource Area, U.S. Bureau of Land Management, Montrose, Colorado, personal communication with C. Burt, Jacobs Engineering Group Inc., UPDCC File Location No. 17.15.1.2, Albuquerque, New Mexico, March 27, 1986.

CDM and Bio/West (Camp, Dresser, \& McKee, Inc. and Bio/West, Inc.), 1983. Biological Assessment Report, Pacific Shale Project, Wheat Ridge, Colorado, and Logan, Utah.

CDOW (Colorado Division of Wildlifel, 1988. "Peregrine Falcon Restoration Program," Job Progress Report (SE-11) for the period 1 January - 31 December, 1987.

CDOW (Colorado Division of Wildlife), 1978. "Essential Habitat for Threatened or Endangered Wildlife in Colorado," Colorado Division of Wildlife, Denver, Colorado.

CDOW (Colorado Division of Wildlife), 1977. "San Miguel River \#1 (Fisheries Survey of the San Miguel River)," Code No. 46842, CDOW, Montrose, Colorado.

Clark et al. (T. W. Clark, T. M. Campbell, M. H. Schroeder, and L. Richardson), 1984. Handbook of Methods for Locating Black-Footed Ferrets, U.S. Bureau of Land Management, Wildlife Technical Bulletin No. 1, Cheyenne, Wyoming.

DOE (U.S. Department of Energy), 1995. Remedial Action Plan and Site Design for Stabilization of the Naturita Title I Residual Radioactive Materials at the Upper Burbank Repository, Uravan, Colorado, final draft, prepared for the U.S. Department of Energy, Environmental Restoration Division, UMTRA Project Team, Albuquerque, New Mexico. 
DOE (U.S. Department of Energy), 1994. "Environmental Assessment of Remedial Action at the Naturita Uranium Processing Site Near Naturita, Colorado," DOE/EA-0464, DOE UMTRA Project Office, Albuquerque Operations Office, Albuquerque, New Mexico.

DOE (U.S. Department of Energy), 1983. "Environmental Assessment of Remedial Actions on the Uranium Mill Tailings at the Naturita site, Montrose County, Colorado," unpublished report, DOE UMTRA Project Office, Albuquerque Operations Office, Albuquerque, New Mexico.

Evans et al. (A. K. Evans, E. W. Uhleman, and P. A. Eby), 1978. Atlas of Western Surface-Mined Lands: Coal, Uranium, and Phosphate, U.S. Fish and Wildlife Service, FWS/OBS-78/20, Fort Collins, Colorado.

Ferguson, J., 1996. Biologist, Bureau of Land Management, Montrose, Colorado, personal communication with C. Burt, Jacobs Engineering Group Inc., UPDCC File Location No. 17.15.1.4, Albuquerque, New Mexico, 19 January 1996.

FWS (Fish and Wildlife Service), 1987. "Recovery Implementation Program for Endangered Fish Species in the Upper Colorado River Basin," FWS, Region 6, Denver, Colorado.

FWS (Fish and Wildlife Service), 1984. "American Peregrine Falcon Recovery Plan (Rocky Mountain/Southwest Population)," prepared in cooperation with the American Peregrine Falcon Recovery Team, FWS, Denver, Colorado.

Hammerson, G. A., 1986. Amphibians and Reptiles in Colorado, Colorado Division of Wildlife, Department of Natural Resources, Denver, Colorado.

Heil, K., 1996. Ecosphere Environmental Services, Farmington, New Mexico, personal communication with C. Burt, Jacobs Engineering Group Inc., UPDCC File Location No. 17.15.1.4, Albuquerque, New Mexico, 19 January 1996.

Heil, K. D., and J. M. Porter, 1987. "Taxonomic Evaluation of Sclerocactus glaucus and its Relationship to Sclerocactus parviflorus Conducted for United States Fish and Wildlife Service Endangered Species," U.S. Fish and Wildlife Service, Grand Junction, Colorado.

Ireland, T., 1995. Biologist, U.S. Fish and Wildlife Service, Grand Junction, Colorado, personal communication with C. Burt, Jacobs Engineering Group inc., UPDCC File Location No. 17.15.1.4, Albuquerque, New Mexico, 6 March 1995.

Jacobsen, K., 1992. U.S. Army Corps of Engineers, Grand Junction, Colorado, personal communication with $\mathrm{C}$. Burt, Jacobs Engineering Group Inc., UPDCC File Location No. 17.15.1.3, Albuquerque, New Mexico, 5 October, 1992. 
Kuchler, A. W., 1975. "Potential Natural Vegetation of the Conterminous United States," American Geographic Society Special Publication No. 36, New York, New York (Map).

Leachman, B., 1990. U.S. Fish and Wildlife Service, Grand Junction, Colorado, personal communication with $\mathrm{C}$. Burt, Jacobs Engineering Group Inc., UPDCC File Location No. 17.15.1.4, Albuquerque, New Mexico, 5 March 1990.

Leachman, B., 1996. U.S. Fish and Wildlife Service, Grand Junction, Colorado, personal communication with C. Burt, Jacobs Engineering Group Inc., UPDCC File Location No. 17.15.1.4, Albuquerque, New Mexico, 20 January 1996.

Nolting, D. R., 1957. "The Effects of Uranium Mill Waste Disposal on the Fish Populations and Aquatic Productivity of the Lower San Miguel and Dolores Rivers," Colorado Department of Game and Fish, Montrose, Colorado.

Opdycke, J. D., 1987. U.S. Fish and Wildlife Service, Grand Junction, Colorado, personal communication with J. Themelis, U.S. Department of Energy, UMTRA Project Office, Albuquerque Operations Office, UPDCC File Location No. 17.15.1.3, Albuquerque, New Mexico, January 13, 1987.

Richardson et al. (B. Z. Richardson, S. B. Monsen, and D. M. Bowers), 1986. "Interseeding Selected Shrubs and Herbs on Mine Disturbances in Southeastern Idaho," in Proceedings - Symposium on the Biology of Artemesia and Chrysothamnus, U.S. Forest Service, Intermountain Research Station, General Technical Report INT-200, Ogden, Utah.

Ricklefs, R. E., 1979. Ecology, Second Edition, Chiron Press, New York, New York.

Rose, K., 1995. Assistant Field Supervisor, Colorado, U.S. Fish and Wildlife Service Grand Junction Colorado, personal communication with Russel Edge, Site Manager, U.S. Department of Energy, Environmental Restoration Division, UMTRA Project Team, UPDCC File Location No. 11.15.1.4, Albuquerque, New Mexico, dated 2 February 1995.

Scott, J., 1985. "The Return of the Peregrine," Colorado Outdoors, March-April, 1986, pp. 30-36.

Sherman, Rick, 1987. Colorado Division of Wildlife, Montrose, Colorado, personal communication with E. Mulford, Jacobs Engineering Group Inc., UPDCC File Location No. 17.15.1.2, Albuquerque, New Mexico, 2 March 1987.

Swenson, E. A., and C. L. Mullins, 1985. "Revegetating Riparian Trees in Southwestern Floodplains," in Riparian Ecosystems and Their Management: Reconciling Conflicting Use, U.S. Forest Service, Rocky Mountain Forest and Range Experiment Station, General Technical Report RM-120, Fort Collins, Colorado. 
TAC (Technical Assistance Contractor), 1995. Unpublished field notes, Naturita, Colorado, uranium mill tailings site, 20, 22, and 23 June 1995, prepared by the TAC, Albuquerque, New Mexico, UPDCC File Location No. 17.15.1.4, for the U.S. Department of Energy, Environmental Restoration Division, UMTRA Project Team, Albuquerque, New Mexico.

TAC (Technical Assistance Contractor), 1994a. Unpublished field notes, Naturita, Colorado, uranium mill tailings site, 13 through 17 June 1994, prepared by the TAC, Albuquerque, New Mexico, for the U.S. Department of Energy, UMTRA Project Office, Albuquerque Operations Office, UPDCC File Location No. 17.15.1.2, Albuquerque, New Mexico.

TAC (Technical Assistance Contractor), 1994b. Unpublished field notes, Naturita, Colorado, uranium mill tailings site, 31 August 1994, prepared by the TAC, Albuquerque, New Mexico, for the U.S. Department of Energy, UMTRA Project Office, Albuquerque Operations Office, UPDCC File Location No. 17.15.1, Albuquerque, New Mexico.

TAC (Technical Assistance Contractor), 1993. "Unpublished Field Notes, Naturita, Colorado, Uranium Mill Tailings Site," 29 June through 1 July 1993, prepared by the TAC, Albuquerque, New Mexico, for the U.S. Department of Energy, UMTRA Project Office, Albuquerque Operations Office, UPDCC File Location No. 17.15.1, Albuquerque, New Mexico.

TAC (Technical Assistance Contractor), 1992. "Unpublished Field Notes, Naturita, Colorado, Uranium Mill Tailings Site," 29 September 1992, prepared by the TAC, Albuquerque, New Mexico, for the U.S. Department of Energy, UMTRA Project Office, Albuquerque Operations Office, UPDCC File Location No. 17.15.1, Albuquerque, New Mexico.

TAC (Technical Assistance Contractor), 1991. "Unpublished Field Notes, Naturita, Colorado, Uranium Mill Tailings Site," 18 through 21 June 1991, prepared by the TAC, Albuquerque, New Mexico, for the U.S. Department of Energy, UMTRA Project Office, Albuquerque Operations Office, UPDCC File Location No. 17.15.1, Albuquerque, New Mexico.

TAC (Technical Assistance Contractor), 1990. "Unpublished Field Notes, Naturita, Colorado, UMTRA Project Site," 11 through 14 June 1990, prepared by the TAC, Albuquerque, New Mexico, for the U.S. Department of Energy, UMTRA Project Office, Albuquerque Operations Office, UPDCC File Location No. 17.15.1, Albuquerque, New Mexico.

TAC (Technical Assistance Contractor), 1988. "Unpublished Field Notes, Naturita, Colorado, Uranium Mill Tailings Site, " 3 November 1988, prepared by the TAC, Albuquerque, New Mexico, for the U.S. Department of Energy, UMTRA Project Office, Albuquerque Operations Office, UPDCC File Location No. 17.15.1, Albuquerque, New Mexico. 
TAC (Technical Assistance Contractor), 1986. "Unpublished Field Notes, Naturita, Colorado, Uranium Mill Tailings Site," 9 and 11 June 1986, prepared by the TAC, Albuquerque, New Mexico, for the U.S. Department of Energy, UMTRA Project Office, Albuquerque Operations Office, UPDCC File Location No. 17.15.1, Albuquerque, New Mexico.

Unitt, P., 1987. "Empidonax traillii extimus: An Endangered Subspecies," in Western Birds, 18:137-162.

Valdez et al. (R. Valdez, P. Mangan, R. Smith, and B. Nilson), 1982. Upper Colorado River Investigation, Rifle, Colorado to Lake Powell, Utah, U.S. Fish and Wildlife Service, Colorado River Fishery Project, Grand Junction, Colorado.

Wagner et al. (W. L. Wagner, W. C. Martin, and E. F. Aldon), 1978. "Natural Succession on Strip-Mined Lands in Northwestern New Mexico," in Reclamation Review, Vol. 1, pp. 67-73.

Welch, Robert, 1993. Uncompahgre Basin Resource Area, Bureau of Land Management, Montrose, Colorado, personal communication with C. Burt, Jacobs Engineering Group Inc., UPDCC File Location No. 17.15.1.4, Albuquerque, New Mexico, 27 May 1993.

Woodward-Clyde (Woodward-Clyde Consultants), 1983. Biological Assessment for Clear Creek Shale Oil Project, Englewood, Colorado.

York, J. C., 1985. "Dormant Stub Planting Techniques," in Riparian Ecosystems and Their Management: Reconciling Conflicting Uses, U.S. Forest Service, Rocky Mountain Forest and Range Experiment Station, General Technical Report RM-120, Fort Collins, Colorado.

\section{CODE OF FEDERAL REGULATIONS}

40 CFR Part 192, Health and Environmental Protection Standards for Uranium and Thorium Mill Tailings, U.S. Environmental Protection Agency. 


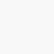


APPENDIX A

CORRESPONDENCE WITH THE FISH AND WILDLIFE SERVICE 



\title{
United States Department of the Interior
}

\author{
FISH AND KILDLIFE SERVICE \\ ENDANGERED SPECIES OFFICE \\ EV 23! ROND \\ RDEPENDENCE PLAZA \\ SUTE - 113 \\ CRAYD JUNCTION. COLOLADO LISCS \\ TELEPHONE: $200-241-0563$ \\ February 27, 1986
}

Mr. Dave Lechel

Marager, Enviromedtal Services

Jacobs Encineerins Group, Inc.

5301 Central Avenue N.W.. Suite 1700

Albuquerque, N.M. 87108

Dear Mr. Lechel:

We have received your letter of January 22, 1986, recardiog Uraniun Mill Tailings Hemediel Action (UrTRA) Project plans of Departaent of Energy for clean-up of uraniwe tailins sites dear Naturita, Montrose County, Colorado, and near Slickrock, Sus Misuel County, Colorado.

We are furnishing you with the following list of rare species which say be present within the area of influence of your project. The lists pertain to both sites with the exception noted below:

\section{rederally Listed Species}

\author{
Bald eagle \\ Black-footed ferret \\ Bonytail chub \\ Colorado squaris ish \\ Bumpack chub \\ Peregrine falcon
}

\author{
Balineetus leucocephalus \\ Mustele nirripes \\ Gila elerans \\ Ptychocheilus Incius \\ Gile cxphe \\ Elco pererrinus (Slickrock site ondy)
}

Bistorically, the esdangered block-footed ferret (Mustela pigripes) way hove occurred in portio.s of soutbwesterc Colorado. Altbough unconfirsed sightings of this ramal have occurred in nortbwestern Colorado, the only known populatios is in Meeteetse, Hyonias. Literature doewents a close association between prairie dogs and black-footed ferrets. The standard that is used for determinias possible project effects to black-footed ferrets is the disturbance of currently occupied prairie dos habits:. Should any of the activities that are part of the above-referenced project result is an inpact to prairie doss, black-footed ferret surveys asy be Decessary.

If mater quality in the Colorado River will be affected by project activities, or If renediel action of any kind results is the consuroptive une of water from the upper Colorado Biver basin, then resultine impacts to the Colorado squentish (Ptvehocheilus lucius), bupbeck chub (Gile cypha), and bonytail cbub (Gils elerans) must be addressed in your assessent of inpacts. 


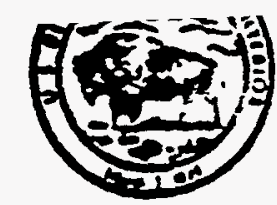

Br Raty retca to.

United States Department of the Interior

FISE AND WIIDIITE SERVICE

FISH AND WILDLIFE ENEANCEMENT

COLORADO STATE OFFICE

529 25:5 Rond, Sulte B-213

GRAND JUNCIION, COLORADO 21505

(303) $243-2778$

(FWE)

May 26, 1988

Bill Glover

Manager. Enviromental Services

Jacobs Engineering Group. Inc.

5301 Central Avenue N.E.. Sufte 1700

Aibuquerque, NH 87108

Dear Mr. Glover.

This responds to your April 25, 1988, letter regarding the Uranium Mill Tailings Remedial Action Project at Naturita, Colorado. It appears that federally listed specfes may occur within the arba of influence of the proposal.

\title{
Eederally Listed Soecies
}

\author{
Black-footed ferret \\ Bald eagle \\ Colorado squawfish \\ Humpback chub \\ Bonytail chub
}

Mustele nieripes

Heliaeetus leucocephalus

Ptrchocheilus lucius

Gile sypho

Gilo elegens

Historically, the black-footed ferret was believed to occar in portions of the construstion work area. Lfterature documents a close assoeiation between prairie dogs and black-footed ferrets. Your pre-construction surveys should determine whether your activities willi disturb prafrie dog colonies. If so, black-footed ferret surveys may be required.

Wintering bald eagles are common throughout colorado and are primarlily associated with streams and reservoirs. Project evaluation should determine. whether baid eagies occur in the project area and whether impacts will occur to this endangered bird.

None of the federally listed fish species occur in the project area. However, we believe it is appropriate at this time to consider whether the proposed projeet will result in a depletion of water from the upper Colorado River basin. If so, formal consultation under the Endangered Species Act will be necessary.

The paradox lupine (Lupinus crassus) is a candidate for federal listing and may occur in the project area. While this plant currently receives no protection from the Endangered Species Act, we believe it is within the spirit of the act to consider potential impacts to this plant at this time. 


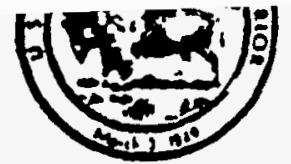

IN azry nema ro.

FISH AND WILDLIFE SERVICE

COLORADO FIELD OFFICE

230 SIMMS STREET

ROOM 292

COLDEN, COLORADO 80401

(FWE)

December 28, 1988

Charles J. Burt

Environnental Specialist

Jacobs Engineering Group. Inc.

5301 Central Avenue N.E. Sulte 1700

Alburquerque, Hew Mexico 87108

Dear Mr. Burt:

This responds to your Hovember 21, 1988. letter requesting an update of Federally listed species that may be associated with the proposed Uranium Mill-talifngs Remedial Action Projects at Slickrock, Naturita, Gunnison and Maybell. Colorado.

We have reviewed the lists provided to Jacobs Engineering. Inc. In 1986 and 1988. The following changes should be made:

1) Neturita site - Delete the Grand Junction milkvetch.

2) Mavbell site - Delete the White River penstemon. Add the bonytail chub.

3) Gunnison site - Add the Colorado squawfish, humpback chub, and bonytail chub.

The list for the slickrock site needs no changes.

We appreciate the opportunity to update the species lists for these actions. Please contact Bob Leachman of our Grand Junction office at (303) 243-2773 if there are any questions.

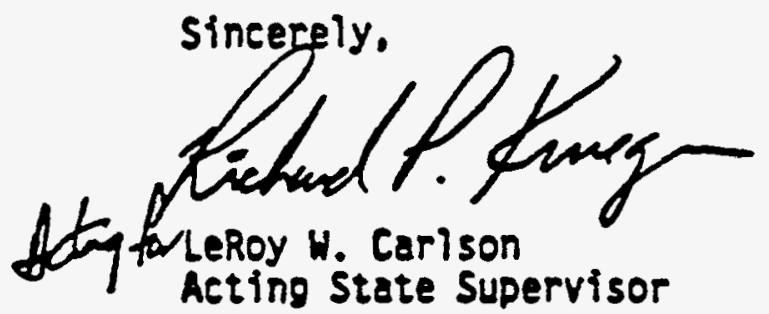

CC: FUS/FHE, Sait Lake City

official File

Reading File 


\section{UNTTED STA"ES DEPARTMENT OF THE INTERIOR FISH AND WILDLIFE SERVICE \\ FISH AND WILDLIFE ENHANCEMENT \\ Western Colorado Sub-Ofince \\ 52925 z Road, Suite B-113 \\ Grand Junction, CO 81505-6199 \\ FTS 332-0351 \\ COMM (303) 243-2778}

IN REPLY REFER TO:

FWE/CO:DOE:UMTRA:Maybell

Mail Stop 65412 Grand Junction

December 4, 1990

Mr. Mark L Matthews

Project Manager

Uranium Mill Tailings Remedial Action Project Office

Department of Energy

P.O. Box 5400

Albuquerque, New Mexico 87115

Dear Mr. Matthews:

This responds to your October 4, 1990 and October 16, 1990, letters forwarding Environmental and Biological Assessments for the Maybell and Naturita Remedial Action Projects. Both projects are in Colorado. Our comments for each project are below.

\section{Maybell Uranium Mill Tailings Site}

This office provided you a draft biological opinion dated November 13, 1990, for remedial action at Maybell, Colorado. This opinion was in response to your October 16 letter to Mr. Lee Carlson of our Golden, Colorado office. We have no further requirements for the Maybell site. We will finalize our draft biological opinion within 30 days of receipt of acknowledgement that the recommended depletion payment has been made to the National Fish and Wildlife Foundation.

Naturita Uranium Mill Tailings Site

\section{Biological Assessment}

We concur with the biological assessment's conclusion that the proposed project "may affect" federally listed fish. Formal consultation under the Endangered Species Act will, therefore, be required for this project.

We have discussed prairie dog distribution with the Bureau of Land Management in Montrose. It appears that more than 250 acres of prairie dogs may occur within 4.5 
UNITED STATES DEPARTMENT OF THE INIERIOR

FISH AND WILLLIFE SERVICE

FISH AND WLDLIFE ENHANCEMENT

Western Colorado Sub-Otice

529 25\% Road, Suite B-113

Grand Junction, CO 81505-6199

FTS $332-0351$

COMM (303) 243-2778

IN REPLY REFER TO:

FWE/GJ-6-CO-90-F-13

December 11, 1990

Mr. Mark L. Matthews, Project Manager

Uranium Mill Tailings Remedial Action Project Office

Department of Energy

Albuquerque Operations Office

P.O. Box 5400

Albuquerque, NM 87115

Subject: Biological Opinion Regarding Remedial Action at the Naturita, Colorado, Uranium Mill Tailings Site

This responds to your October 1, 1990, letter initiating Section 7 consultation under the Endangered Species Act of 1973, as amended. The Fish and Wildlife Service (Service) has reviewed your biological assessment and concurs with your "may affect" determination for Colorado squawfish (Ptychocheilus lucius), humpback chub (Gila cypha), and bonytail chub (Gila elegans), which are all federally listed as endangered. The fourth species addressed in your biological assessment, the razorback sucker (Xyrauchen texanus) is currently proposed for listing as endangered. It is the Department of Energy's (DOE) responsibility to confer with the Service on any action which is likely to jeopardize the continued existence of any proposed species (50 CFR Part 402.10). Your biological assessment made the determination that the proposed action "may affect" the razorback sucker; however, the regulations require that the DOE determine whether the proposed action is likely to jeopardize the continued existence of the razorback sucker. Please submit your determination to this office for our concurrence.

We concur with your assessment that the proposed action would not affect the bald eagle (Haliaeetus leucocephalus) or black-footed ferret (Mustela nigripes). We appreciate your concern and effort in evaluating impacts the project may have on candidate species. Your report on the willow flycatcher (Empidomax trailii) was very informative and will be used to document the likelyhood of these birds being found in other areas of Colorado in similar habitats. 
Arizona (Seethaler 1978). Colorado squawfish were apparently never found in colder, headwater areas. Seethaler (1978) indicates that the species was abundant in suitable habitat throughout the entire Colorado River basin prior to the 1850's. Historically, Colorado squawfish have been collected in the upper Colorado River as far upstream as Parachute Creek, Colorado (Kidd 1977).

A marked decline in Colorado squawfish population; can be closely correlated with the construction of dams and reservoirs during the 1960's, the introduction of nonnative fishes, and the removal of water from the Colorado River system. Behnke and Benson (1983) summarized the decline of the natural ecosystem. They pointed out that dams, impoundments, and water use practices are probably the major reasons for drastically modified natural river flows and channel characteristics in the Colorado River Basin. Dams on the mainstem have essentially segmented the river system, blocking Colorado squawfish spawning migrations and drastically changing river characteristics, especially flows and temperatures. In addition, major changes in species composition have occurred due to the introduction of nonnative fishes, many of which have thrived as a result of changes in the natural riverine system (i.e., flow and temperature regimes). The decline of endemic Colorado River fishes seems to be at least partially related to competition or other behavioral interactions with nonnative species, which have perhaps been exacerbated by alterations in the natural fluvial environment.

The Colorado squawfish currently occupies about 1,030 river miles in the Colorado River system ( 25 percent of its original range) and is presently found only in the upper Colorado River Basin above Glen Canyon Dam. It inhabits about 350 miles of the mainstem Green River from its mouth to the mouth of the Yampa River. Its range also extends 140 miles up the Yampa River and 104 miles up the White River, the two major tributaries of the Green River. In the mainstem Colorado River, it is currently found from Lake Powell extending about 201 miles upstream to Palisade, Colorado, and in the lower 33 miles of the Gunnison River, a tributary to the mainstem Colorado River (Tyus et al. 1982). Recent investigation found adult Colorado squawfish inhabit the San Juan River as far upstream as 163.3 miles above Lake Powell.

The life stages that appear to be most critical are from egg fertilization through its first year of life. It has been demonstrated that these phases of Colorado squawfish development are also closely tied to some specific habitat requirements. It is imperative that proper flows and temperatures are provided during these essential life stages. The conservation measures outlined below will help further investigate and meet the habitat requirements of the Colorado squawish, thus offsetting project-related impacts and the likelihood of jeopardy for the species.

\section{HUMPBACK CHUB}

Humpback chub generally do not make migrational movements in the upper Colorado River and tend to reside throughout the year within a limited reach of river. Humpback chub are found inhabiting narrow, deep canyon areas, and are relatively restricted in 
It is important to note that these provisions of the Recovery Program were based on appropriate legal protection of the instream flow needs of the endangered Colorado River fishes. The Recovery Program further states:

"...it is necessary to protect and manage sufficient habitat to support self-sustaining populations of these species. One way to accomplish this is to provide long term protection of the habitat by acquiring or appropriating water rights to ensure instream flows.... Since this program sets in place a mechanism and a commitment to assure that the instream flows are protected under State law, the Service will consider these elements under Section 7 consultation as offsetting project depletion impacts."

Thus, the Service has determined that project depletion impacts, which the Service has consistently maintained are likely to jeopardize the listed fishes, can be offset by (a) the water project proponents one-time contribution to the Recovery Program in the amount of $\$ 10.91$ per acre-foot of the project's average annual depletion, and (b) appropriate legal protection of instream flows pursuant to State law. The Service believes it is essential that protection of instream flows proceed expeditiously, before significant water depletions occur.

With respect to (a) above (i.e., depletion charge), the applicant will make a one-time payment which has been calculated by multiplying the project's average annual depletion (37 acre-feet) by the depletion charge in effect at the time payment is made. For fiscal year 1991 (October 1, 1990, to September 30, 1991), the depletion charge is $\$ 10.91$ per acre-foot of the average annual depletion which equals a total payment of $\$ 403.67$ for this project. This amount will be adjusted annually for inflation on October 1 of each year based on the previous year's Composite Consumer Price Index. The Service will notify the DOE of any change in the depletion charge by September 1 of each year. Ten percent of the total contribution (\$40.37) or total payment, will be made to the National Fish and Wildlife Foundation (see Appendix A). The balance will be due at the time the construction commences. Fifty percent of the funds will be used for acquisition of water rights to meet the instream flow needs of the endangered fishes (unless otherwise recommended by the Implementation Committee); the balance will be used to support other recovery activities for the Colorado River endangered fishes.

\section{Conclusion}

This concludes our biological opinion on the impacts of proposed remedial action. This opinion was based upon the information described herein. If new information becomes available, new species listed, or should there be any changes in the total average annual amount of water depleted by this project ( 37 acre-feet per year) or any other project change which alters the operation of the project from that which is described in the biological assessment and which may affect any endangered or threatened species in a 


\section{REFERENCES}

Behnke, R.J., and D.E. Benson. 1983. Endangered and threatened fishes of the Upper Colorado River Basin. Ext. Serv. Bull. 503A, Colorado State University, Fort Collins, CO. $38 \mathrm{pp}$.

Kidd, G. 1977. An investigation of endangered and threatened fish species in upper Colorado River as related to Bureau of Reclamation Projects. Final report, Bureau of Reclamation, Salt Lake City. 36 pp.

Seethaler, K. 1978. Life History and Ecology of the Colorado Squawfish (Ptychocheilus lucius) in the upper Colorado River basin. Thesis, Utah State University, Logan, Utah.

Tyus, H.M., B.D. Burdick, R.A. Valdez, C.M. Haynes, T.A. Lytle, and C.R. Berry. 1982. Fishes of the Upper Colorado River Basin: Distribution, abundance and status. pp. 12-70. In: Miller, W.H., H.M. Tyus and C.A. Carlson, (eds) 1982. Fishes of the Upper Colorado River System: Present and Future. Western Division, American Fisheries Society, Bethesda, MD.

U.S. Fish and Wildlife Service (Service. 1982. Colorado River Fishery Project Final Report. Part I (42 pp), Part II (356 pp), and Part III (342 pp). Prepared for the U.S. Bureau of Reclamation, Salt Lake City. April 1982.

U.S. Fish and Wildlife Service, 1987. Recovery Implementation Program for Endangered Fish Species in the Upper Colorado River Basin. U.S. Fish and Wildlife Service, Denver, Colorado. 82 pp.

Vanicek, C.D., and R.H. Kramer. 1969. Life history of the Colorado squawfish Ptychocheilus lucius and the Colorado chub Gila robusta in the Green River in Dinosaur National Monument, 1964-1966. Trans. AFS 98(2):193- 
Cooperative Agreement

between

U.S. Department of the Interior

Fish and Wildlife Service

and

National Fish and Wildlife Foundation

\section{Background}

Three species of fish that inhabit the Colorado River system have been federally 7isted as endangered: the Colorado squawfish, humpback chub, and bonytail chub. A fourth, the razorback sucker, is currently a candidate for listing. On January 21-22, 1988, the Governors of Utah, Hyoming, and Colorado, the Administrator of the Western Area Power Administration, and the Secretary of the Interior executed a Cooperative Agreement to implement the "Recovery Implementation Program for Endangered Fish Species in the Upper Colorado River Basin" (Recovery Program). The 15-year Recovery Program out ines an aggressive effort to recover the endangered fishes of the Colorado River in a manner that is consistent with Interstate Compacts and State water rights systems. The signing of the Cooperative Agreement al so established an Implementation Committee whose purpose is to oversee the Fish and Wildlife Service's (Service) implementation of the Recovery Program. Members of the Implementation Committee include representatives of the States of Colorado, Wyoming, and Utah, the Service, the Bureau of Reclamation, the Western Area Power Administration, and representatives of the water development interests and environmental groups.

The cost for implementing the Recovery Program is estimated at $\$ 58.5$ million over the 15-year time frame. Contributions by proponents of water projects (Federal, State and private) are expected to provide approximately \$9-10 million of these funds, assuming full Compact development over the next 15 years. Water project proponents will make a one-time contribution to the Service in the amount of $\$ 10$ per acre-foot based on the average annual depletion of projects that complete consultation pursuant to Section 7(a)2 of the Endangered Species Act of 1973, as amended. Payment of the contribution will be specified in the biological opinion for each water project which causes a depletion of water from the Upper Colorado River system. Ten percent of the funds will be payable upon completion of the Federal action which initiated the consultation (e.g., issuance of a 404 permit); the balance will be due at the time construction commences or prior to the depletion becoming effective. Funds from these contributions are to be applied equally to flow acquisition and other priority recovery activities, uniess otherwise directed by the Implementation committee.

In addition, the Recovery Program has a provision for the donation of funds from private parties, including conservation groups. Private donations would be used for priority recovery activities as agreed to by the donor, the Service, and/or the Implementation Comittee.

The role of the National Fish and Wildlife Foundation (Foundation) was identified in the Recovery Program. Section 5.5 indicates that all contributed or donated funds accruing from the Recovery Program, regardless of source, will be placed in an interest bearing account, such as those administered by the Foundation, until such time as they are utilized in accorience with the Implementation Committee's approved annual work plan and budget. 
4. Work closely with the Foundation to develop contracts for work to be funded with Colorado River contributed/donated funcs.

5.- Appoint a technical project officer for all contracts or projects carried out or funded under this Agreement.

6. Appoint an individual who will represent the Service in carrying out its obligations under this Agreement, including authorizing the expenditure of funds by the Foundation.

7. In cases dealing with disbursement of funds for acquiring water rights, provide the Foundation with written direction of the Service's Director or his designee, and a certified resolution of the Implementation Comittee recommending allocation of the funds. The resolution will contain the following information:
a. The specific purpose for which the funds are being disbursed.
b. A detailed description of the water right to be acquired.
c. The owner of the water right.
d. The exact or maximum amount to be expended in acquiring the water right.

8. Coordinate and report upon activities of the Foundation with and to the Colorado River Implementation Committee, including providing an annual accounting to the Implementation Committee for all funds maintained, received, and/or expended pursuant to this Agreement.

9. Continue to maintain separate accounts for funds appropriated by Congress for the acquisition of water rights, and contributed/donated funds received prior to the implementation of this Agreement. Use of funds in these accounts will be coordinated by the Service, on behalf of the Implementation Committee, with those maintained by the Foundation under this Agreement.

B. Foundation Obligations - The Foundation will:

1. Serve as the Service's designated agent for accepting and administering contributed and donated funds acquired pursuant to the Recovery Program, and disbursing these funds as approved by the Service and the Implementation Committee.

2. Haintain these funds in a specific account, separate from other. Foundation accounts. Interest accruing to this foundation account will be used for the purpose for which the account was established.

3. Develop and/or issue, in coordination with the Service, contracts for work to be funded with Colorado River contributed/donated funds as identified in the approved Implementation Committee work plan.

4. Appoint an individual. who will represent the Foundation in carrying out its obligations under this Agreement. 
1X. Amendments

Amendments to this Agreement may be proposed by either party, and shall become effective only upon being reduced to a written instrument executed by both parties.

X. Termination

This Agreement may be terminated by either party upon 90 days written notice to the other. Upon receipt of such written notice, the Foundation will provide an accounting of remaining funds and outstanding contractual obligations of funds. In the case of termination, the Service will make arrangements for transferring the funds administered by the Foundation to another entity, or renegotiate an a)ternative agreement with the foundation.

\section{General Provisions}

The U.S. Fish and Wildlife Service General Provisions for Grant and Cooperative Agreements, as attached, shall be applicable to this Agreement.

In witness whereof, each party has caused this Agreement to be executed by an authorized official on the day and year set forth below their signature.

National Fish and Wildlife Foundation.

B) ( TITLE ExcuEn Duitor DATE $5 / 19 / 89$
U.S. Fish and Wildi ife Service

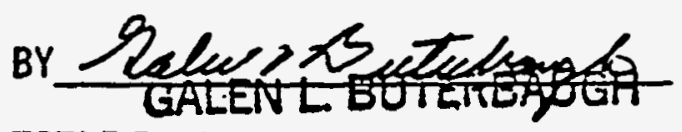

TITLE Regional Director

DATE JUN 141989 


\section{Process and Schedule \\ Colorado River Endangered Fishes \\ Annual Work Plan}

December 31 Each Principal Investigator provides a written summary of results of studies and identifies successes, shortcomings and plans for the next year. An oral presentation is provided at the Colorado River annual researcher's meeting in February.

March 15 Chairman of Technical Group sends out a request for preliminary proposals for new projects.

June 15 Technical Group meets to rank existing (ongoing) projects and preliminary proposals for new projects. Each project is ranked based on several factors, including:

a. consistency with the Recovery Program/PIans

b. degree of urgency (to avoid jeopardy)

c. essential for recovery

d. timeliness of study results

e. likelihood of success

f. relationship to other priority work

g. opportunity to do project now

h. quality of proposal

Recommendations are provided to the Management Group on the relative priority of funding existing and new (proposed) projects.

July 15 Management Group considers the recommendations of the Technical Group, determines available funding, and prepares draft work plan. Management Group transmits a draft work plan to Implementation Committee for review.

September 1 Implementation Committee meets to review and approve the annual work plan.

Sept-Dec . Cooperators develop and/or issue requests for proposals, scopesof-work, and contracts for projects approved in the Implementation Committee's work plan.

January 31 Implementation Committee meets to review the status of projects contained in their annual work plan. 
UNITED STATES DEPARTMENT OF THE INTERIOR

FISH AND WILDLIFE SERVICE

FSH AND WIDDLIFE ENHANCENENT

Weatern Colondo Sub-Ofice

529 25/6 Rad, Suite B-113

㳔

FIS 332-0351

Grand Junction, CO $21505-6199$

FAX: (303) 245-6933

PHONE: (303) 243-2778

N REPLY REFER TO:

FWE/CO:DOE:UMTRA

Mail Stop 65412 Grand Junction

February 25, 1991

Mark L Matthews, Project Manager

Uranium Mill Tailings Remedial Action Project

Department of Energy

P.O. Box 5400

Albuquerque, New Mexico 87115

Dear Mr. Matthews:

This responds to your three letters dated February 7, 1991, regrading remedial action activities at the Gunnison, Maybell, and Naturita Uranium Mill Tailings sites.

Each of the above letters serve as a biological assessment for the razorback sucker

. (proposed for Federal listing on May 22, 1990), as required under Section 402.12 of 50 CFR 402. We concur with your conclusion that remedial action activity at each of the sites is not likely to jeopardize the continued existence of the razorback sucker. Further action under Section 7 of the Endangered Species Act is, therefore, not necessary for any of the above projects.

We appreciate your attention to endangered species issues. Please contact me if there are any questions.

Sincerely,

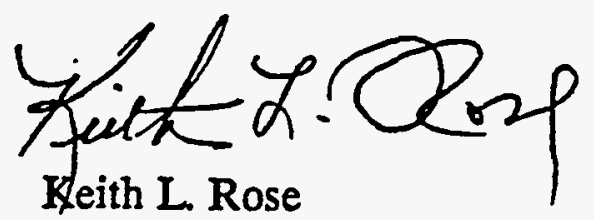

Acting Colorado State Supervisor

cc: FWS/FWE, Golden

FWS/FWE, Salt Lake City

CDOW, Grand Junction

CDOW, Montrose 
UNTEU STATES DEPARTMENT OF THE INTERIOR

FISH AND WLDLIFE SERVICE

ECOLOGICAL SERVICES

Festere Colorado Ontice

$52925 \frac{1}{2}$ Road, Suite B-113

Grand Junction, CO 81505-6199

Phone: (303) 243-2778

FAX (303) 245-6933

IN REPLY REFER TO:

ES/CO:DOE-UMTRA

MS 65412 GJ

Apri7 20, 1993

Ms. Linda Ul land, Manager

Environmental Services

Jacobs Engineering Group, Inc.

5301 Central Avenue N.E., Suite 1700

Albuquerque, New Mexico 87108

Subject: Naturita UMTRA Project update

Dear Ms. Uliand:

This responds to your March 15, 1993 request for guidance regarding the need to update the biological assessment for the Naturita Colorado Uranium Mill Tailings Remedial Action (UMTRA) Project. As you state in your letter, the Fish and Hildlife Service provided a biological opinion dated December 11, 1990 (FWE/GJ-6-CO-90-F-13) regarding this activity. Due to the need to evaluate other alternatives, the conservation measures included in that opinion to protect federaliy listed fish species were not implemented. Even though the current project description is not changed from that evaluated in the biological opinion, we believe it is necessary to re-evaluate the potential impacts of this project to federally listed and candidate species due to changes in the status of federally listed fish species, and some of the candidate species. Consequently, we are providing you the following list of federaliy listed and candidate species that may occur within the area of influence of the proposed project.

\section{FEDERALLY LISTED SPECIISS}

Colorado squawfish

Humpback chub

Bonytail chub

Razorback sucker

Bald eagle

Black-footed ferret
Ptychocheilus lucius.

Gila cypha

Gila elegans

Xyrauchen texanus

Haliaeetus leucocephalus

Lustela niaripes

He have provided Jacob's Engineering biological details regarding the federally listed fish species on numerous occasions; consequently, we are abbreviating this response. However, you should be advised that critical habitat for the federally listed fish species was proposed for designation on January 24, 1993 (Federal Register V58 No. 18). The proposal identifies 2,094 river miles of the Colorado river and its tributaries that are believed to have the essential biological and physical elements required for the conservation of the federally listed fish. The Fish and Wildlife Service will consider any depletion of water from the upper Colorado River basin as an adverse modification of this critical habitat, a conclusion which will require formal conferencing (50CFR402.10) by the Department of Energy with this 
disturbed by any phase of the project. The prairie dog inventory should occur on all lands within a one/half mile radius of all project feature boundaries.

\section{FEDERAL CANDIDATE SPECIES}

\author{
Ferruginous hawk \\ Loggerhead shrike \\ Northern goshawk \\ Southwestern willow flycatcher \\ White-faced ibis \\ Columbian sharptailed grouse \\ Roundtaif chub \\ Flanneimouth sucker \\ Lupinus crassus
}

\author{
Buteo regalis \\ Lanius Iudovicianus \\ Accipiter gentilis \\ Empidomax trailii extimus \\ Pleqadis chihi \\ Tympanuchus phasianellus columbianus \\ Gila robusta \\ Catostomus latipinnis \\ Paradox Tupine
}

The ferruginous hawk is the largest buteo in North America and is a category 2 listing candidate. It is a common summer resident of grass lands in Rio Blanco County, occasional7y nests in pinon-juniper woodlands, and feeds on small mammals such as prairie dogs and rabbits. Human disturbance near active nest sites can result in nesting failure. A petition to list the ferruginous hawk was recently determined unwarranted by the Fish and Wildlife Service. However, there is a need to continue monitoring the status of this candidate species.

The loggerhead shrike is a category two listing candidate species. The shrike may be found in a variety of habitats below 6,000 feet elevation, including riparian areas and pinyon-juniper woodlands. The shrike is a fairly common summer resident and spring and fall migrant in Colorado. The loggerhead shrike may feed on large insects, smali birds, or mice. The loggerhead shrike has shown significant population declines over much of its range. It has been extirpated from some areas in eastern Colorado, but appears stable in western Colorado. It is a rare to uncommon winter resident in western valleys north to Mesa County and on the southeastern plains north to the southern El Paso County. The loggerhead shrike has also been identified by the Partners in Flight international joint venture as a neotropical migrant worthy of attention.

The northern goshawk is a category two listing candidate. The goshawk is associated with aspen, ponderosa pine, and lodgepole pine between 7,500 and 11,500 feet elevation. Migrants and winter residents are seen on ail types of coniferous forest, riparian forest, and occasionally shrublands. Goshawks feed primarily on other birds. The northern goshawk has also been identified by the Partners in Flight international joint venture as a neotropical migrant worthy of attention. Your project activities should be evaluated to determine whether impacts will occur to goshawks or their habitat. Pre-project surveys may be necessary.

The southwestern willow flycatcher is a category two listing candidate. It is a riparian obligate, usually found associated with Fremont cottonwood, Gooding willow, and tamarisk along slow moving watercourses. It is entirely insectivorous. There are no records of this species from Colorado, but it is 
habitat types including riffles, runs, eddies, and backwaters. It feeds on invertebrates, and spawns in early Hay to eariy August. Competition with exotic species and/or cold water releases from reservoirs are reasons for their disappearance from the upper Gunnison River, and could impact their distribution elsewhere. Your project evaluation should include... For additional information regarding this species biology and distribution in Colorado, contact this office, or the Colorado River Fishery Project at 303245-9319.

We are aware that surveys were conducted for the Paradox lupine during preparation of the biological assessment in 1990. You should contact Dr. Lucy Jordan with this office to determine whether additional surveys are needed.

He have provided Jacob's Engineering numerous letters regarding the process required to satisfy section 7 of the Endangered Species Act; consequent7y, we do not believe it is necessary to remind Jacobs' Engineering of these requirements in this letter. However, we do request that Jacob's Engineering consider alternatives to the tentative proposal to remove approximately 40 acres of cottonwood trees from the San Miguel River riparian corridor. Even if there is no potential impact to wintering bald eagles, riparian corridors provide important habitat for numerous other species of wildi ife.

Due to the water depletion associated with this project, it appears that formal consultation and conferencing will be required to bring this issue to closure under the requirements of the Endangered Species Act. We appreciate your attention to endangered species issues, and the effort you dedicate to the candidate species that may occur in the area. Please contact me or Bob Leachman if there are any questions.

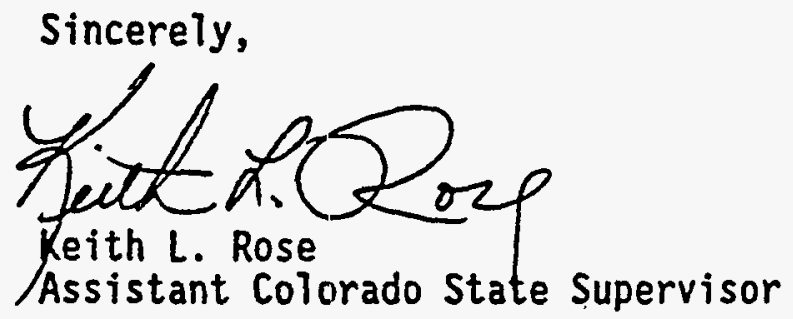

cc: FWS/Ecological Services, Golden

FHS/Ecological Services, Salt Lake City CDOW, Montrose 


\section{United States Department of the Interior}

FISH AND WILDLIFE SERVICE

Ecological Services

Western Colorado Office

764 Horizon Drive, South Arnex A

IN RERLY REFER TO;

Grand Juncrion, Colorado 81506-3946

ES/CO:DOE-Naturita UMTRA

MS 65412 GJ

December 15, 1995

L.A. Woodworth, Naturita Site Manager

Department of Energy

Albuquerque operations office

P.0. Box 5400

Albuquerque, New Mexico 87185-5400

Dear Mr. Woodworth:

This responds to your December 1, 1995, letter requesting a list of species for the revision to the plan for uranium mill tailings remedial action near Naturita, Colorado.

Federally Listed Species

Colorado squawfish
Humpback chub
Razorback sucker
Bonytai1
Peregrine falcon
Bald eagle
Southwestern willow flycatcher
Black-footed ferret
Sclerocactus glaucus

Colorado squawfish

Humpback chub

Razorback sucker

Bonytail

Peregrine falcon

Bald eagle

Black-footed ferret

Sclerocactus glaucus

\author{
Ptychocheitus lucius \\ Gila cypha \\ Xyrauchen texanus \\ Gila elegans \\ Falco peregrinus \\ Haliaeetus leucocephalus \\ Empidonax traillii extimus \\ Mustela nigripes \\ Uinta Basin hookless cactus
}

The Fish and Wildlife Service has redefined its list of Federal candidate species. Consequentiy, there are no Federal candidates occurring in the project area.

Section $7(c)$ of the Endangered Species Act, as amended, requires that the Department of Energy prepare and submit to the Service a biological assessment to determine effects of the proposal on listed species. The biological assessment shall be completed within 180 days after the date on which initiated or a time mutually agreed upon between the agency and the Service. The assessment must be completed before physical project modification/alteration begins. If the biological assessment is not begun within 90 days, the species list above should be verified prior to initiation of the assessment. Due to our frequent coordination with your office in the past, we assume you are familiar with the other Endangered Species Act consultation requirements at 50 CFR 402. 
Thank you for the opportunity to provide these conments on the revised plan. Please contact me or Bob Leachman at the letterhead address or (970) 243-2778, if there are any questions.

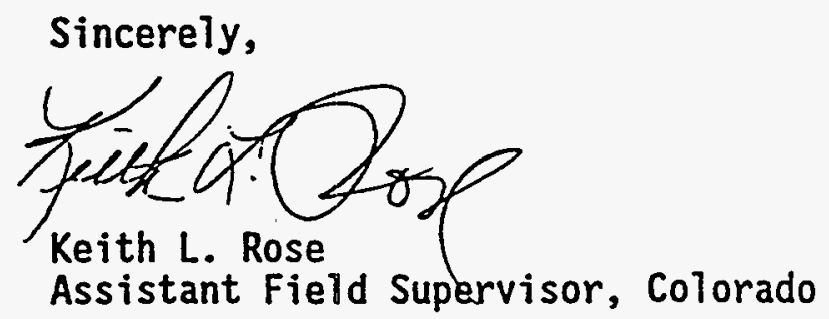

cC: FWS/ES, Golden

CDOW, Montrose

BLM, Montrose (Attn: Jim Ferguson)

BLeachman:DOEKatrV.Itr:121595 